Published in final edited form as:

Cochrane Database Syst Rev. ; (1): CD005451. doi:10.1002/14651858.CD005451.pub2.

\title{
Carbamazepine for acute and chronic pain in adults
}

\author{
Philip J Wiffen ${ }^{1}$, Sheena Derry ${ }^{2}$, R Andrew Moore ${ }^{2}$, and Henry J McQuay ${ }^{2}$ \\ ${ }^{1}$ UK Cochrane Centre, Oxford, UK. \\ ${ }^{2}$ Pain Research and Nuffield Department of Clinical Neurosciences (Nuffield Division of \\ Anaesthetics), University of Oxford, Oxford, UK
}

\begin{abstract}
Background-Carbamazepine is used to treat chronic neuropathic pain.

Objectives-Evaluation of analgesic efficacy and adverse effects of carbamazepine for acute and chronic pain management (except headaches).
\end{abstract}

Search methods-Randomised controlled trials (RCTs) of carbamazepine in acute, chronic or cancer pain were identified, searching MEDLINE, EMBASE, SIGLE and Cochrane CENTRAL to June 2010, reference lists of retrieved papers, and reviews.

Selection criteria-RCTs reporting the analgesic effects of carbamazepine.

Data collection and analysis-Two authors independently extracted results and scored for quality. Numbers needed to treat to benefit (NNT) or harm (NNH) with $95 \%$ confidence intervals (CI) were calculated from dichotomous data for effectiveness, adverse effects and adverse event withdrawal. Issues of study quality, size, duration, and outcomes were examined.

Main results-Fifteen included studies (12 cross-over design; three parallel-group) with 629 participants.

Carbamazepine was less effective than prednisolone in preventing postherpetic neuralgia following acute herpes zoster ( 1 study, 40 participants). No studies examined acute postoperative pain.

Fourteen studies investigated chronic neuropathic pain: two lasted eight weeks, others were four weeks or less (mean 3 weeks, median 2 weeks). Five had low reporting quality. Ten involved

Copyright @ 2012 The Cochrane Collaboration. Published by John Wiley \& Sons, Ltd

Contact address: Philip J Wiffen, UK Cochrane Centre, National Institute for Health Research, Summertown Pavilion, Middle Way, Oxford, OX2 7LG, UK. phil.wiffen@nden.ox.ac.uk. phil.wiffen@nden.ox.ac.uk.

CONTRIBUTIONS OF AUTHORS PW registered the title, wrote the protocol, carried out searching and identified studies for inclusion. PW \& RAM carried out data extraction, analysis, and drafting. All authors contributed to the final draft and approved the published version.

Editorial group: Cochrane Pain, Palliative and Supportive Care Group.

Publication status and date: Stable (no update expected for reasons given in 'What's new'), published in Issue 8, 2012.

Review content assessed as up-to-date: 15 September 2011.

DECLARATIONS OF INTEREST All authors have received research support from charities, government or industry sources at various times. RAM and HJM have consulted for various pharmaceutical companies. RAM, and HJM have received lecture fees from pharmaceutical companies related to analgesics and other healthcare interventions. Support for this review came from Oxford Pain Research, the NHS Cochrane Collaboration Programme Grant Scheme, and NIHR Biomedical Research Centre Programme.

NOTES This review has been substantially amended following a search for new trials up to June 2010. 
fewer than 50 participants; mean and median maximum treatment group sizes were 34 and 29. Outcome reporting was inconsistent.

Most placebo controlled studies indicated that carbamazepine was better than placebo. Five studies with 298 participants provided dichotomous results; 70\% improved with carbamazepine and $12 \%$ with placebo. Carbamazepine at any dose, using any definition of improvement was significantly better than placebo (70\% versus $12 \%$ improved; 5 studies, 298 participants); relative benefit 6.1 (3.9 to 9.7), NNT 1.7 (1.5 to 2.0). Four studies (188 participants) reporting outcomes equivalent to $50 \%$ pain reduction or more over baseline had a similar NNT.

With carbamazepine, $66 \%$ of participants experienced at least one adverse event, and $27 \%$ with placebo; relative risk 2.4 (1.9 to 3.1), NNH 2.6 (2.1 to 3.5). Adverse event withdrawals occurred in 12 of 323 participants (4\%) with carbamazepine and 0 of 310 with placebo. Serious adverse events were not reported consistently; rashes were associated with carbamazepine. Five deaths occurred in patients on carbamazepine, with no obvious drug association.

Authors' conclusions-Carbamazepine is effective in chronic neuropathic pain, with caveats. No trial was longer than four weeks, of good reporting quality, using outcomes equivalent to at least moderate clinical benefit. In these circumstances, caution is needed in interpretation, and meaningful comparison with other interventions is not possible.

\section{Medical Subject Headings (MeSH)}

Acute Disease; Analgesics, Non-Narcotic [adverse effects; *therapeutic use]; Anticonvulsants [adverse effects; therapeutic use]; Carbamazepine [adverse effects; *therapeutic use]; Chronic Disease; Neuralgia [drug therapy]; Neuralgia, Postherpetic [drug therapy]; Pain [*drug therapy]; Randomized Controlled Trials as Topic

\section{MeSH check words}

Adult; Humans

\section{BACKGROUND}

This updated review was originally published in The Cochrane Library as 'Anticonvulsant drugs for acute and chronic pain' (2000, issue 2). At the third update in 2003, 12 new included studies were identified mainly of the newer anticonvulsants gabapentin and lamotrigine. In total the included studies provided data on six different medicines used in at least six identified neuropathic pain conditions. Issues of dose response and trial design added to the complexity. A decision was therefore taken to split that review into a number of smaller reviews each covering one medicine (chemical entity). This review looks at the evidence for carbamazepine. Reviews of gabapentin (Wiffen 2005) and pregabalin (Moore 2009a) have also been completed.

Anticonvulsant drugs currently used for neuropathic pain are: carbamazepine, clonazepam, gabapentin, lamotrigine, oxcarbazepine, phenytoin, topiramate, and valproate; licensed status may vary between regions. Pregabalin is also licensed in some countries for neuropathic pain and the evidence for this has been reviewed (Moore 2009a). 
Anticonvulsant drugs have been used in pain management since the 1960s (Blom 1962), very soon after they were first used in medicine and revolutionised the medical management of epilepsy. The clinical impression is that they are useful for neuropathic pain, especially when the pain is lancinating or burning (Jacox 1994). Primary care incidences per 100,000 person years observation of 28 (95\% CI 27 to 30) for post-herpetic neuralgia, 27 (26 to 29) for trigeminal neuralgia, 0.8 (0.6 to 1.1) for phantom limb pain and 21 (20 to 22) for painful diabetic neuropathy have been reported in the UK (Hall 2008). Incidence varies between studies, often because of small numbers of cases, and a study of facial pain in The Netherlands found incidences per 100,000 person years of 12.6 for trigeminal neuralgia and 3.9 for postherpetic neuralgia (Koopman 2009). A systematic review of chronic pain incidence demonstrated that some neuropathic pain conditions, like painful diabetic neuropathy, can be more common, with prevalence rates up to 400 per 100,000 person years (McQuay 2007). Some forms of neuropathic pain, like diabetic neuropathy and post surgical chronic pain, which is often neuropathic in origin, are increasing (Hall 2008).

Although these disorders are not common, they can be very disabling. Chronic pain is also associated with substantial changes to the brain, to the extent that chronic pain is argued to be a disease in its own right (Tracey 2009). Effective pain relief is associated with large improvements in associated symptoms like depression, fatigue, sleep problems, quality of life, and work (Hoffman 2010; Moore 2010a).

In addition to use in epilepsy, carbamazepine is licensed in the UK for paroxysmal pain of trigeminal neuralgia (up to $1600 \mathrm{mg}$ daily). The precise mechanisms of action of anticonvulsant drugs in relation to relief of neuropathic pain remain uncertain, but they reduce the ability of the neuron to fire at high frequency (Chong 2000). The two standard explanations are enhanced gamma-aminobutyric acid inhibition (valproate, clonazepam) or a stabilising effect on neuronal cell membranes. A third possibility is action via N-methyl-Daspartate (NMDA) receptor sites. pain that manifests in different diseases may operate through common mechanisms however the same symptom in two patients may be caused by different mechanisms. It is therefore impossible to predict the mechanisms responsible for an individual's pain based on the aetiology of the neuropathy or on the distribution or nature of symptoms (Woolf 1999). Carbamazepine is thought to work by blocking voltage sensitive sodium channels, meaning that fewer of these channels are available to open, making brain cells less excitable (less likely to fire).

Anticonvulsant drug use is not without risk: serious adverse effects have been reported, including deaths from haematological reactions (blood dyscrasias; Sweetman 2005) and lifethreatening cutaneous problems (Chung 2010). The commonest adverse effects are impaired mental and motor function, which may limit clinical use, particularly in older people (Grahame-Smith 1992; Rall 1992; Sweetman 2005).

\section{OBJECTIVES}

The purpose of this review was to evaluate the analgesic effectiveness of carbamazepine in acute and chronic pain and to evaluate adverse effects reported in the studies. 


\section{METHODS}

\section{Criteria for considering studies for this review}

Types of studies-Studies were included in this review if they were RCTs investigating the analgesic effects of carbamazepine in patients, with pain assessment as either the primary or a secondary outcome. We excluded studies which were: non-randomised, of experimental pain, case reports, clinical observations or studies of carbamazepine used to treat pain produced by other drugs.

Migraine and headache studies previously included in an earlier version of this review were excluded. This subject is being dealt with in greater depth by the Cochrane Pain, Palliative Care and Supportive Care Review Group.

Types of participants-Adult participants. A wide range of neuropathic pains were considered including: trigeminal neuralgia, post-herpetic neuralgia, diabetic neuropathy, HIV related neuropathy, central pain after stroke, irritable bowel, and temporomandibular joint dysfunction pain. Other types of acute or chronic pain would be accepted if found, but the known use of carbamazepine is in neuropathic pain.

Types of interventions-Administration of carbamazepine, any dose, by any route to provide relief of pain.

Types of outcome measures-Information about the pain condition and number of patients studied, anticonvulsant drug and dosing regimen, study design (placebo or active control, parallel or cross-over), study duration and follow-up, analgesic outcome measures and results, withdrawals and adverse effects (minor and major) was taken from each report using a data extraction sheet.

A variety of outcome measures were used in the studies, the majority using standard subjective scales for pain intensity and/or pain relief.

A hierarchy of outcome measures was agreed as follows:

1. Patient reported pain relief of $50 \%$ or greater

2. Patient reported global impression of clinical change

3. pain on movement

4. pain on rest or spontaneous pain

5. Any other pain related outcomes

6. Adverse events

In addition, pain outcomes equivalent to at least moderate benefit (at least $30 \%$ pain reduction over baseline) and substantial benefit (at least 50\% pain reduction over baseline) recommended by the Initiative on Methods, Measurement, and Pain Assessment in Clinical Trials (IMMPACT) group were sought (Dworkin 2008). During the updating process consensus was being discussed concerning a common core data set for pain reviews, and to 
reflect that we also used a working set of seven outcomes that might form a core data set, and this overlapped to some extent to outcomes already identified:

- At least $50 \%$ pain reduction

- Proportion below 30/100 mm (no worse than mild pain)

- Patient global impression

- Functioning

- Adverse event withdrawal

- $\quad$ Serious AE

- Death

\section{Search methods for identification of studies}

Studies were identified by several methods. RCTs of anticonvulsants in acute, chronic or cancer pain were identified by MED-LINE (Silver Platter 3.0, 3.1 and 3.11) from 1966 to June 2010, EMBASE 1994 to Dec 2009, SIGLE 1980 to July 1999, and CENTRAL (Issue 4,2010 ). This search strategy was narrowed to include carbamazepine only. Additional studies were identified from the reference list of the retrieved papers, and by contacting investigators. Appendix 1 has the MEDLINE and EMBASE search strategies.

For the first version of this review, 41 medical journals were hand searched, chosen from the 50 with the highest number of reports in MEDLINE, and nine specialist journals which were either not on that list or were not indexed (Jadad 1994). The search process included volumes published between 1950 and 1990. No further hand searching has been undertaken as the key journals are now being searched by the Cochrane Collaboration.

\section{Data collection and analysis}

Eligibility was determined by reading each study identified by the search. All studies were read by two review authors and agreement was reached by discussion. Only RCTs were included. The studies were not anonymised in any way prior to assessment. Intention-totreat analysis was not carried out and patients who dropped out of studies were not included in the analysis.

In the first version, a letter was sent to the first author of a report for further information on their published report (method of randomisation, double blinding, outcome measures and dropouts) and to ask if they knew of any other studies which met our inclusion criteria, either undertaken by them or by other investigators. Dichotomous data were used to calculate relative risk or benefit with 95\% CIs using a fixed-effect model, together with numbers-needed-to-treat-to-benefit (NNTs) (Cook 1995). This was done for effectiveness, for adverse effects and for drug-related study withdrawal. Meta-analysis was also undertaken when appropriate data were available. NNTs were calculated as the reciprocal of the absolute risk reduction (McQuay 1998). For unwanted effects, the NNT becomes the NNH (number-needed-to-treat-to-harm), and is calculated in the same way. 
Assessment of risk of bias in included studies-Each report was scored independently for quality by three of the authors using a three-item scale (Jadad 1996b). They then met to agree a 'consensus' score for each report. Quality scores were not used to weight the results in any way.

The three item scale is as follows:

Is the study randomised ? If 'yes', then 1 point.

If described, is the randomisation appropriate? If 'yes' add 1 point, if not deduct 1 point.

Is the study double blind ? If 'yes', then 1 point.

Is the double blind method appropriate ? If 'yes' add 1 point, if not deduct 1 point.

Are withdrawals and dropouts described? (i.e., the number and reason for drop-outs for each of the treatment groups)

If 'yes', add 1 point.

Scores of two and below have been associated with greater estimates of efficacy than studies of higher quality (Khan 1996). In this update, a 'Risk of bias' table was completed for randomisation, allocation concealment, blinding, size, duration, incomplete outcome assessment, and outcome.

In the process of completing the review, a more extensive list of potential biases was published (Moore 2010b). This added duration (less than 2 weeks, 2-6 weeks, 8-12 weeks), outcome (typically pain reduction less than $30 \%$ of baseline, pain intensity reduction $30 \%$ from baseline, pain intensity reduction 50\% from baseline, though with other definitions), incomplete outcome assessment (how pain measures are dealt with on withdrawal), and treatment arm size ( 50, 50-199, and 200 patients per treatment arm) as potential sources of bias, with definitions that could be used in risk of bias tables in Cochrane reviews. This updated procedure has been used in this review.

\section{RESULTS}

\section{Description of studies}

See: Characteristics of included studies; Characteristics of excluded studies; Characteristics of studies awaiting classification.

In this update, 23 potentially relevant studies ( 24 publications) were identified, of which 15 studies (16 publications) are included (629 participants, 447 receiving carbamazepine). One study is awaiting assessment Liebel 2001. Two studies awaiting assessment in the previous version have now been processed (Harke 2001; Wilton 1974); however, two further studies have been identified but are not available for inclusion (Badran 1975; Liebel 2001). Details of included studies are given in the 'Characteristics of included studies'. In an earlier version of this review data were requested from 19 authors but only one (Leijon 1989) was able to 
supply information relevant to this review. In this update, no further attempt was made to contact authors.

A wide range of carbamazepine doses, ranging from $100 \mathrm{mg}$ to $2400 \mathrm{mg}$ daily, were used for in these studies (Nicol 1969). Crossover studies predominated; only three had a parallel group design (Gerson 1977; Jia 2006; Vilming 1986). A single study in acute herpes zoster examined whether carbamazepine reduced later development of postherpetic neuralgia (Keczkes 1980). Chronic pain conditions studies included trigeminal neuralgia, painful diabetic neuropathy, postherpetic neuralgia, and post stroke pain.

Many of the studies were relatively old, with five published in the 1960's. Only one study (Jia 2006) has been published in the last ten years. A consequence of the age of the studies is that outcomes - pain, adverse event, and discontinuation - were reported inconsistently. Pooling of trial data in meta-analyses was therefore problematical, because few studies reported the same outcomes in the same way in the same condition.

\section{Risk of bias in included studies}

Out of a maximum of five points, one study scored 5 points, five scored 4 points, three scored 3 points, and five scored 2 points on the Oxford Quality Scale. Points were lost due to studies not being double blind (Gerson 1977; Keczkes 1980; Rasmussen 1970) or failure to adequately report withdrawals or details of the randomisation and blinding processes. Scores for individual trials are reported in the notes section of 'Characteristics of Included Studies' table.

A risk of bias table was completed for randomisation, allocation concealment and blinding. Three studies were potentially at high risk of bias due to issues around blinding (Gerson 1977; Keczkes 1980; Rasmussen 1970) and allocation concealment (Rasmussen 1970) (Figure 1).

There are three other potential sources of bias in the included studies, relating to size, duration, and outcome.

Numbers of participants were small ranging from 9 to 132 in chronic pain studies (mean 40, median 30 participants). Studies were small because 12 of the 15 studies were cross-over and only three were three parallel-group studies (Gerson 1977; Jia 2006; Vilming 1986); mean and median maximum treatment group sizes were 34 and 29 participants. Small studies can be associated with larger treatment effects than bigger studies (Counsell 1994; Moore 1998a; Moore 1998b).

Chronic pain studies were short, and while duration of the intervention ranged from two three-day crossover comparisons (Rockliff 1966) to 42 months (Nicol 1969), studies were generally four weeks or shorter (mean three weeks, median two weeks). Only two eightweek studies lasted more than four weeks (Gerson 1977; Lechin 1989). Chronic pain studies of six weeks or less have been shown to manifest greater treatment effects than those of eight weeks or more (Moore 2009b). 
A variety of different pain outcomes was reported, including average pain scores, raw individual pain scores (though not always complete), dichotomous outcomes like the proportion with any improvement or benefit, including scores (like global impression of change) equivalent to IMMPACT outcomes of moderate or substantial benefit (Dworkin 2008); some studies gave little or no indication of how many patients benefited from treatment. Higher levels of benefit (e.g. 50\% pain relief rather than any pain relief) result in higher NNTs (Moore 2009b).

The question of whether cross-over trials exaggerate treatment effects in comparison with parallel group designs, as has been seen in some circumstances (Khan 1996), is a general effect is unclear (Elbourne 2002). The predominance of cross-over trials in this review has to be considered as a possible source of additional bias. In these circumstances, caution is needed in interpreting the data as far as efficacy is concerned. In particular, meaningful comparison of efficacy with other interventions is not possible.

\section{Effects of interventions}

Fifteen studies were suitable for inclusion. Three additional studies were included in this updated review. Details of results in individual studies are presented in Appendix 2.

Acute pain-Comparing carbamazepine $400 \mathrm{mg}$ daily with prednisolone (40 $\mathrm{mg}$ daily for 10 days reducing to zero over three subsequent weeks) in the management of acute herpes zoster, participants treated with prednisolone reported less pain and faster skin healing on average ( 3.7 weeks compared to 5.3 weeks) than those treated with carbamazepine. At two months 13 of 20 carbamazepine participants developed postherpetic neuralgia compared with 3 of 20 treated with prednisolone (Keczkes 1980).

No studies were found that investigated carbamazepine for the treatment of established acute pain after surgery, including third molar extraction.

Chronic pain-Studies in chronic pain all involved neuropathic pain. We could find no randomised studies that tested carbamazepine in musculoskeletal conditions like arthritis or back pain, or other chronic painful conditions.

Trigeminal neuralgia-Eight studies of carbamazepine in trigeminal neuralgia were identified. Two of these (Killian 1968; Rasmussen 1970) also recruited some participants with other neuralgias; one reported results on trigeminal neuralgia separately (Rasmussen 1970), while in the other 30 of 42 participants had trigeminal neuralgia (Killian 1968).

Five were placebo-controlled (Campbell 1966; Killian 1968; Nicol 1969; Rasmussen 1970, Rockliff 1966). Using dose titration to a maximum daily dose of $1000 \mathrm{mg}, 19$ of 27 participants had a complete or very good response with carbamazepine compared with minimal or no response with placebo on five days' treatment in a subset of patients with trigeminal neuralgia (Killian 1968). Again using dose titration and a cross-over design, but to a maximum daily dose of $2400 \mathrm{mg}, 15$ of 20 participants randomised to initial carbamazepine had a good or excellent response after 14 days' treatment, compared with 6 of 24 reporting good or excellent response who started on placebo (Nicol 1969). Superiority 
of carbamazepine was also claimed by Rockliff (Rockliff 1966) in a small study of nine participants with three days' treatment with carbamazepine, but no evaluable data were presented. The study from Rasmussen 1970 contained a mixture of typical trigeminal neuralgia, atypical neuralgia and a 'non neuralgiform' group. The study was not blinded, and appears to have been conducted without patient consent (states 'patients not informed'). The outcomes used were 'good effect' (after five days, 46 of 55 with trigeminal neuralgia had good effect on carbamazepine, compared with 8 of 55 on placebo), though it is not clear what this means in terms of pain relief.

A study by Campbell 1966 reported results by the number of changes in the pain score; this study has been removed from the analyses in this version as the numbers presented in the paper are events rather than patient data. It had claimed a mean fall in maximum pain intensity of 58\% after two weeks with carbamazepine 400 to $800 \mathrm{mg}$ daily compared to $26 \%$ with placebo.

Combining the short-term results for any measure of benefit from the studies with dichotomous pain relief outcomes (Killian 1968; Nicol 1969; Rasmussen 1970) produced, in 208 participants, a relative benefit for carbamazepine compared to placebo of 5.9 (3.6 to 9.6), and a NNT of 1.5 (1.3 to 1.8). Restricting the analysis to randomised and double blind studies (Killian 1968; Nicol 1969) produced, in 98 participants, a relative benefit for carbamazepine compared to placebo of 6.0 (2.8 to 13), and a NNT of 1.7 (1.3 to 2.2).

Three active controlled studies were identified. Carbamazepine was compared with tizanidine (an alpha-2 adrenergic agonist for spasticity associated with multiple sclerosis or spinal cord injury) (Vilming 1986), tocainide (an antiarrhythmic drug) (Lindstrom 1987) and pimozide (an antipsychotic drug) (Lechin 1989). Carbamazepine produced better results than tizanidine over three weeks in a total of 12 participants; there was no significant difference in the tocainide study in 12 participants over two weeks; pimozide produced better results than carbamazepine in 59 participants over eight weeks.

Diabetic neuropathy-Four studies evaluated carbamazepine in diabetic neuropathy (Gomez-Perez 1996; Jia 2006; Rull 1969; Wilton 1974).

Two were placebo controlled (Rull 1969; Wilton 1974). In a complicated three-way crossover, Rull 1969 found that, using the top two levels of pain improvement (3 points or better out of 5), in the first two of three cross-over periods for each group, 17 of 30 improved with carbamazepine and 2 of 30 for placebo. The other study (Wilton 1974) reported only on preferences after one week of treatment with carbamazepine and placebo; 24 of 40 preferred carbamazepine, 14 of 40 preferred placebo, and 2 of 40 had no preference.

Two active controlled studies met the inclusion criteria. One compared carbamazepine 200 $\mathrm{mg}$ to a nortriptyline $10 \mathrm{mg}$ plus fluphenazine $0.5 \mathrm{mg}$ combination over four weeks (GomezPerez 1996). No significant difference was found between carbamazepine and the nortriptyline combination; both treatments improved paraesthesia and pain. Jia 2006 compared venlafaxine with carbamazepine over two weeks in 132 participants, with both 
drugs given at fixed and relatively low dose. Both drugs demonstrated effect with venlafaxine showing a somewhat larger mean effect.

Post-herpetic neuralgia-An active-controlled study (Gerson 1977) compared a combination of carbamazepine (up to $1000 \mathrm{mg}$ daily) plus clomipramine (up to $75 \mathrm{mg}$ daily) with transcutaneous electronic nerve stimulation (TENS) in 29 participants over eight weeks. The study authors report that the drug combination was superior to TENS in terms of pain relief: 50\% pain intensity reduction or more was achieved by 7 of 16 and 0 of 13 with drug combination and TENS respectively, and $30 \%$ pain intensity reduction or more was achieved by 8 of 16 and 0 of 13 respectively.

Post stroke pain-A cross-over study compared carbamazepine, amitriptyline, and placebo, with a treatment duration of four weeks for each (Leijon 1989). Global report of any improvement occurred in 10 of 15 on amitriptyline, 5 of 15 on carbamazepine, and 1 of 15 on placebo.

Overall estimation of efficacy-Five studies with 298 participants contributed dichotomous outcomes of the highest available definition of improvement for carbamazepine and placebo (Killian 1968; Leijon 1989; Nicol 1969; Rasmussen 1970; Rull 1969), though over relatively short treatment duration (Analysis 1.1). The results were consistent (Figure 2), and overall 70\% of patients improved on carbamazepine compared with $12 \%$ on placebo. Carbamazepine at any dose, and using any definition of improvement, was significantly better than placebo (Figure 3), with a relative benefit of 6.1 (3.9 to 9.7) and NNT of 1.7 (1.5 to 2.0) (Summary of results A). Results did not change in any major way by restriction to randomised and double blind trials (Summary of results A).

Using data from 188 participants in four studies (Killian 1968; Leijon 1989; Nicol 1969; Rull 1969) with an outcome equivalent to the IMMPACT outcome of substantial improvement gave a $60 \%$ response rate with carbamazepine and $10 \%$ with placebo, with an NNT of 1.9 (1.6 to 2.5). Using the lowest level of benefit in the five studies gave an $80 \%$ response rate with carbamazepine and 23\% with placebo, with an NNT of 1.7 (1.5 to 2.1).

\section{Summary of results A: Efficacy outcomes with carbamazepine in postherpetic neuralgia Withdrawals-}

\begin{tabular}{lllllll}
\hline \multicolumn{2}{l}{ Number of } & Percent with outcome & & \\
\hline Outcome & Studies & Participants & Carbamazepine & Placebo & $\begin{array}{l}\text { Relative } \\
\text { benefit (95\% } \\
\text { CI) }\end{array}$ & NNT (95\% CI) \\
\hline Pain relief & & & & & & \\
\hline Highest level available & 5 & 298 & 70 & 12 & $\begin{array}{l}6.1(3.9 \text { to } \\
9.7)\end{array}$ & 1.7 (1.5 to 2.0) \\
\hline IMMPACT substantial & 4 & 188 & 61 & 10 & $\begin{array}{l}6.5(3.4 \text { to } \\
12)\end{array}$ & 1.9 (1.6 to 2.5) \\
\hline Lowest level available & 5 & 298 & 81 & 23 & $\begin{array}{l}3.5(2.6 \text { to } \\
4.8)\end{array}$ & 1.7 (1.5 to 2.1) \\
\hline
\end{tabular}




\begin{tabular}{|c|c|c|c|c|c|c|}
\hline \multirow[b]{2}{*}{ Outcome } & \multicolumn{2}{|c|}{ Number of } & \multicolumn{4}{|c|}{ Percent with outcome } \\
\hline & Studies & Participants & Carbamazepine & Placebo & $\begin{array}{l}\text { Relative } \\
\text { benefit }(95 \% \\
\text { CI) }\end{array}$ & NNT $(95 \%$ CI $)$ \\
\hline $\begin{array}{l}\text { Highest level available } \\
\text { (restricted to randomised } \\
\text { and double blind) }\end{array}$ & 4 & 188 & 61 & 10 & $\begin{array}{l}6.5(3.4 \text { to } \\
12)\end{array}$ & $1.9(1.6$ to 2.5$)$ \\
\hline \multicolumn{7}{|l|}{ Other outcomes } \\
\hline Adverse event withdrawal & 9 & 573 & 4 & 0 & not calculated & \\
\hline At least one $\mathrm{AE}$ & 4 & 346 & 66 & 27 & $\begin{array}{l}2.4 \text { (1.9 to } \\
3.1)\end{array}$ & $2.6(2.1$ to 3.5$)$ \\
\hline
\end{tabular}

Withdrawals - Nine studies provided information on adverse event withdrawals with carbamazepine (Campbell 1966; Gomez-Perez 1996; Killian 1968; Lechin 1989; Leijon 1989; Lindstrom 1987; Nicol 1969; Rasmussen 1970; Wilton 1974). In these studies, 12 of 323 participants (4\%) withdrew because of adverse events with carbamazepine, compared with 0 of 310 with placebo. There were a further three adverse event withdrawals from 16 participants on a combination of carbamazepine and clomipramine (Gerson 1977).

At least one adverse event-Four studies provided information on participants experiencing at least one adverse event (Campbell 1966; Lechin 1989; Leijon 1989; Wilton 1974). Adverse event experience was more common with carbamazepine (66\% of participants) than placebo (27\%), relative risk 2.4 (1.9 to 3.2), NNH 2.6 (2.1 to 3.5 ) (Summary of results A).

Serious adverse events-Serious adverse events were not reported consistently, and that included the absence of negative statements that there were no serious adverse events. Only one study (Gomez-Perez 1996) reported an adverse event as serious, a case of upper gastrointestinal bleeding thought to be associated with alcohol rather than carbamazepine. Rashes associated with carbamazepine were reported byRasmussen 1970 (3) and Rull 1969 (2); these may be considered serious because of association with Stevens-Johnson syndrome.

Deaths-Five deaths occurred on carbamazepine. Nicol 1969 reported four deaths; Two participants died suddenly, presumably of cardiovascular disease, one had a brain tumour, and one died of progressive debilitating disease. Rasmussen 1970 reported one death associated with cardiovascular disease.

Specific adverse effects-Specific adverse events reported at high incidence (>10\%) included giddiness, dizziness, unsteadiness, and somnolence. These were not reported in sufficient detail to be combined, but the incidence of somnolence and dizziness was as high as $40-60 \%$ on carbamazepine. 


\section{DISCUSSION}

Much has been written about how to justify the use of our long-established medical interventions. While the randomised controlled trial (RCT) is the gold standard for the assessment of health care technologies and interventions (DOH 1992), buttressed by double blinding when the outcome measures are subjective (Colditz 1989; Schulz 1994; Turner 1994), the fact remains that many interventions are time-honoured rather than RCThonoured. On whom then does the burden of proof fall? (Eddy 1993). The aim of this systematic review was to review the effectiveness and safety of the anticonvulsant drug carbamazepine in the management of pain. Since the first version of this review, gabapentin has become established as a treatment for neuropathic pain, and is now licensed for this indication in a number of countries. More recently both lamotrigine and pregabalin have been assessed in chronic pain studies. These agents are considered in other Cochrane reviews (Moore 2009a; Wiffen 2005; Wiffen 2007).

\section{Summary of main results}

Carbamazepine generally provided better pain relief than placebo in a comparison that included several different chronic neuropathic pain conditions (trigeminal neuralgia, painful diabetic neuropathy, postherpetic neuralgia, and central post stroke pain). Five placebocontrolled studies provided some indication of pain improvement over the short term, with $70 \%$ improving on carbamazepine compared with $12 \%$ with placebo, leading to an NNT of 2. However, these were short term studies, with poorly defined outcomes, in only 298 participants (only a tenth of the number of participants available for one dose of pregabalin, for instance; (Moore 2009a). The NNH for minor harm was 4, though again reporting was neither consistent nor complete.

There is no evidence for carbamazepine being effective in established acute pain, and very limited evidence for any efficacy in acute herpes zoster.

What we have is a good indication that carbamazepine can produce good levels of pain relief for some patients with distressing chronic painful conditions.

\section{Overall completeness and applicability of evidence}

The problems are:

- Limited size, with all but two studies involving fewer than 60 participants.

- Short duration, with all but two studies being four weeks or less in treatment duration.

- Inadequate outcomes, with inconsistent reporting not allowing outcomes equivalent to IMMPACT outcomes of at least moderate benefit to be assumed.

Despite this, carbamazepine has been used with good effect in many patients suffering chronic neuropathic pain, and the results that we do have support this.

Poor quality reporting limited the ability to combine data, because many studies reported insufficient information, used a variety of different outcome measures, and several studies 
used variable dosing. Although the authors of the original reports were originally contacted by letter, not all of them replied, and of those who did, only Leijon 1989 was able to provide additional data.

Doses of carbamazepine used in some of the studies were small; Gomez Perez, for example, used $200 \mathrm{mg}$ daily, which while effective in some is not effective in all (Taylor 1981). Dose escalation was rapid in some studies, potentially resulting in adverse effects. Although carbamazepine takes 2-4 days to achieve its maximum effect, autoinduction of enzymes that metabolise the drug, which is complete at three weeks, often means that late dose increases are needed. These factors are largely ignored, and this limits the applicability of the available evidence.

These studies do not provide adequate information about adverse events, and in particular serious adverse events. This is of particular importance for serious cutaneous adverse events in particular parts of the world. A strong genetic association between HLAB*1502 and carbamazepine-induced Stevens-Johnson syndrome and toxic epidermal necrolysis has been shown in Han Chinese (Chung 2010), Indian (Mehta 2009), and Thai (Tassaneeyakul 2010) populations, and Asian populations generally may be more susceptible. While the frequency of this allele is low in Europe, its frequency in Asian populations is 5-10\% (Chung 2010). Carbamazepine is the most common causative agent for Stevens-Johnson syndrome and toxic epidermal necrolysis in Europe (8\% of total), rising to $26 \%$ in Taiwan, $36 \%$ in Malaysia and 28\% in Singapore (Chung 2010).

There is also an interaction between carbamazepine and warfarin metabolism which can be of major clinical importance (Herman 2006). If treatment with carbamazepine cannot be avoided, patients taking warfarin should be frequently monitored, especially when initiating or stopping carbamazepine therapy

\section{Quality of the evidence}

Several possibilities exist for bias: 5 of 14 chronic pain studies had quality scores of 2 of 5 on the Oxford Quality Scale, studies were small, short, and with inadequate definition of benefit. For each of these there is some evidence that they could be the source of systematic bias, and this significantly reduces the weight we can give the evidence we have. In particular, it limits comparability of carbamazepine results with results for other interventions obtained from larger, longer, and better studies and meta-analyses.

In order to be sure that carbamazepine works in chronic painful conditions and to be confident of the magnitude of the effect, the ideal would be several large randomised double blind studies comparing carbamazepine at sensible doses with placebo, over 8-12 weeks, and using IMMPACT outcomes (perhaps at least moderate improvement or benefit) or their equivalent in each of several clinical conditions, as we have for pregabalin, for example (Moore 2009a). We actually have only two studies of sufficient duration; one using a combination of carbamazepine and clomipramine (Gerson 1977) with 29 participants in postherpetic neuralgia had a quality score of 2 of 5 and reported an IMMPACT equivalent outcome, while the other (Lechin 1989), with 59 participants in trigeminal neuralgia, had a quality score of 4 of 5 but reported only an undefined improvement. 


\section{Potential biases in the review process}

Criteria for assessing potential biases in chronic pain are becoming more stringent as new biases are being discovered (Moore 2010b). Potential biases in the review process derive from including studies with the potential for bias, though the review has sought to highlight the potential for bias when it occurs.

Using only criteria of sufficient stringency to avoid all these potential biases would reduce the pool of included studies to nil, which, given that carbamazepine is used to treat neuropathic pain, is less than helpful.

\section{Agreements and disagreements with other studies or reviews}

The results of this review are generally in agreement with the previous version. We are not aware of any other systematic reviews specifically concerning carbamazepine, but a broad overview of interventions for neuropathic pain (Finnerup 2005) had a combined NNT for efficacy of 2.0 (1.6-2.5), very similar to our estimate of 1.7 (1.5 to 2.0). The source of the small difference cannot be ascertained from details provided.

\section{AUTHORS' CONCLUSIONS}

\section{Implications for practice}

Acute pain-Carbamazepine was ineffective in acute herpes zoster (Keczkes 1980). There is no logic in using anticonvulsants to manage acute nociceptive pain when there are effective pain relieving drugs. Carbamazepine has no obvious place in the treatment of acute pain.

Chronic pain-The use of carbamazepine in neuropathic pain has stood the test of time and is likely to be chosen in situations where treatment cost is of prime importance. These studies indicate that for every two patients with neuropathic pain treated with carbamazepine at least one will achieve at least moderate pain relief in the short term who would not have done with placebo; overall about $70 \%$ achieve some level of pain relief. However, the numbers of participants in trials is generally small and study duration short.

Medical students are often taught that a positive response to carbamazepine is 'diagnostic' for trigeminal neuralgia. While about $70 \%$ of patients respond with carbamazepine, $30 \%$ do not, and $12 \%$ respond with placebo. If only one patient responds out of two treated this statement needs to be qualified. One caveat is that the study populations may include patients who have had other interventions, such as nerve blocks, and the NNT for effectiveness may be more impressive in trigeminal neuralgia treated with carbamazepine in the initial stages. Clinically it appears that trigeminal neuralgia can become refractory to carbamazepine.

The usual clinical decision for chronic neuropathic pain is a choice between antidepressant and anticonvulsant as first-line treatment, and there is insufficient evidence to support the use of carbamazepine as first line. In addition the need for laboratory monitoring and significant drug interactions with the use of carbamazapine have discouraged the use of carbamazepine with the emergence of newer compounds like gabapentin and pregabalin. 


\title{
Implications for research
}

This review shows that there is still a need for large, high quality, long duration studies using sensible outcomes to establish relative effectiveness of different anticonvulsants in chronic pain syndromes, and for comparisons of other treatments such as antidepressants with anticonvulsants; appropriate trial designs have been suggested for this (Moore 2009c) The usefulness of such studies would be increased greatly by improvements in the quality of reporting, and particularly with use of clinically important end points rather than undefined improvement. Investigators presenting data as means for treatment and control should also consider the (simple) presentation of categorical and binary data. It is unlikely that the pharmaceutical industry will conduct further studies of carbamazepine but national funding agencies might be willing to investigate this drug further. Enriched enrolment randomised withdrawal studies have real potential (McQuay 2008).

\section{Acknowledgments}

SOURCES OF SUPPORT

Internal sources

- $\quad$ No sources of support supplied

External sources

- Marie Curie Cancer Care for earlier version of this review, UK.

- $\quad$ NHS R\&D funds, UK.

- $\quad$ NIHR Biomedical Research Centre Programme, UK.

Support for RAM

\section{CHARACTERISTICS OF STUDIES}

\section{Characteristics of included studies [ordered by study ID]}

\author{
Campbell 1966
}

\begin{tabular}{ll}
\hline Methods & Multicentre, randomised, double blind, placebo controlled, cross-over. Not \\
enriched. & Duration 8 weeks (4 two-week periods) \\
\hline Participants & Trigeminal neuralgia \\
& $\mathrm{N}=77$ (but 7 excluded, 6 for logistic problems, one for a rash) \\
& 36 started on carbamazepine, 34 (report says 35 in one place) started on placebo \\
& Age range 20 to 84 (mean 59) years. Male $34 \%$ \\
\hline Interventions & CBZ $100 \mathrm{mg} 4 \times$ daily to $200 \mathrm{mg} 3 \times$ daily (1 centre), or $200 \mathrm{mg} 4 \times$ daily $(2$ \\
& centres) \\
& Placebo \\
& Order of treatment CBZ, P, CBZ, P or P, CBZ, P, CBZ \\
\hline Outcomes & Pain intensity: 4 point scale to determine "upgrading" \\
& Frequency of paroxysms and triggers \\
& Adverse events \\
Withdrawals
\end{tabular}




\begin{tabular}{|c|c|c|}
\hline Bias & Authors' judgement & Support for judgement \\
\hline $\begin{array}{l}\text { Random sequence generation } \\
\text { (selection bias) }\end{array}$ & Low risk & 'random number lists' \\
\hline $\begin{array}{l}\text { Allocation concealment (selection } \\
\text { bias) }\end{array}$ & Unclear risk & $\begin{array}{l}\text { 'neither patient nor doctor knowing the order of } \\
\text { therapy given' }\end{array}$ \\
\hline $\begin{array}{l}\text { Blinding (performance bias and } \\
\text { detection bias) } \\
\text { Active and controlled appeared } \\
\text { similar }\end{array}$ & Low risk & $\begin{array}{l}\text { 'placebo indistinguishable in appearance from active } \\
\text { drugs' }\end{array}$ \\
\hline Duration & High risk & two week treatment period \\
\hline Outcome & High risk & upgrading not level of change \\
\hline Incomple outcome assessment & Unclear risk & not stated \\
\hline Size & High risk & group size below 50 \\
\hline
\end{tabular}

Gerson 1977

\begin{tabular}{|c|c|}
\hline Methods & $\begin{array}{l}\text { Randomised, open, active control, parallel group. Not obviously enriched. } \\
\text { Duration 8-10 weeks } \\
\text { No follow-up }\end{array}$ \\
\hline Participants & $\begin{array}{l}\text { Postherpetic neuralgia } \\
\mathrm{N}=29 \\
\text { Age and sex not reported }\end{array}$ \\
\hline Interventions & $\begin{array}{l}\text { CBZ } 150 \mathrm{mg} \text { to } 1000 \mathrm{mg} \text { daily plus clomipramine } 10 \text { to } 75 \mathrm{mg} \text { daily; } \mathrm{N}=16 \text {. (Note } \\
\text { potentially high dose of CBZ) } \\
\text { TENS } 15 \mathrm{mins} \text { per week for } 4 \text { weeks; } \mathrm{N}=13 \\
\text { Four participants who did not benefit from drug treatment were allowed to cross } \\
\text { over to TENS. Eight who did not benefit on TENS crossed to drug treatment }\end{array}$ \\
\hline Outcomes & $\begin{array}{l}\text { Pain intensity: VAS, categorical? (responder }=>50 \% \text { reduction in pain, }>30 \% \\
\text { reduction in pain) } \\
\text { Adverse events } \\
\text { Withdrawals }\end{array}$ \\
\hline Notes & Oxford Quality Score: $\mathrm{R}=1, \mathrm{DB}=0, \mathrm{~W}=1$, Total $=2$ \\
\hline \multicolumn{2}{|l|}{ Risk of bias } \\
\hline Bias & Support for judgement \\
\hline $\begin{array}{l}\text { Random sequence generation } \\
\text { (selection bias) }\end{array}$ & 'patients randomly allocated' \\
\hline $\begin{array}{l}\text { Allocation concealment } \\
\text { (selection bias) }\end{array}$ & No statement \\
\hline $\begin{array}{l}\text { Blinding (performance bias and } \\
\text { detection bias) } \\
\text { Active and controlled appeared } \\
\text { similar }\end{array}$ & Open-label study \\
\hline Duration & $8-10$ weeks \\
\hline Outcome & $250 \%$ responder \\
\hline Incomple outcome assessment & Unclear risk \\
\hline Size & group size below 50 \\
\hline
\end{tabular}

\section{Gomez-Perez 1996}




\begin{tabular}{|c|c|c|}
\hline Methods & \multicolumn{2}{|c|}{$\begin{array}{l}\text { Randomised, double blind, double dummy, active controlled, cross-over (washout } \\
\text { and phase } 2 \text { only). Duration two } 30 \text { day treatment periods plus washout. Not } \\
\text { obviously enriched }\end{array}$} \\
\hline Participants & \multicolumn{2}{|c|}{$\begin{array}{l}\text { Adult patients with diabetic neuropathy - severe pain } \\
\mathrm{N}=16 \\
\text { Age and sex not stated }\end{array}$} \\
\hline Interventions & \multicolumn{2}{|c|}{$\begin{array}{l}\text { CBZ } 300 \mathrm{mg} \text { to } 600 \mathrm{mg} \text { daily } \\
\text { Nortriptyline } 10 \mathrm{mg} \text { plus fluphenazine } 0.5 \mathrm{mg} \text { combination ( } 3 \text { to } 6 \text { tablets daily) } \\
\text { Dose increment over } 3 \text { days then stable to day } 15 \text { then double dose for next } 15 \\
\text { days } 2 \text { to } 4 \text { weeks washout then cross-over }\end{array}$} \\
\hline Outcomes & \multicolumn{2}{|c|}{$\begin{array}{l}\text { Symptom intensity for pain and paraesthesia: Vertical VAS } 0-100 \% \\
\text { Withdrawals } \\
\text { Adverse events }\end{array}$} \\
\hline Notes & \multicolumn{2}{|c|}{$\begin{array}{l}\text { Oxford Quality Score: } \mathrm{R}=1, \mathrm{DB}=2, \mathrm{~W}=1 \text {, Total }=4 \\
\text { Geigy supplied the drugs }\end{array}$} \\
\hline \multicolumn{3}{|l|}{ Risk of bias } \\
\hline Bias & Authors' judgement & Support for judgement \\
\hline $\begin{array}{l}\text { Random sequence generation } \\
\text { (selection bias) }\end{array}$ & Unclear risk & 'randomly assigned' \\
\hline $\begin{array}{l}\text { Allocation concealment (selection } \\
\text { bias) }\end{array}$ & Unclear risk & No statement \\
\hline $\begin{array}{l}\text { Blinding (performance bias and } \\
\text { detection bias) } \\
\text { Active and controlled appeared } \\
\text { similar }\end{array}$ & Low risk & $\begin{array}{l}\text { 'an identical placebo tablet of the } \\
\text { comparing drug was given simultaneously } \\
\text { with the active drug' Double dummy } \\
\text { design }\end{array}$ \\
\hline Duration & Unclear risk & 4 week treatment periods \\
\hline Outcome & Low risk & At least $50 \%$ decrease of pain \\
\hline Incomple outcome assessment & Unclear risk & not stated \\
\hline Size & High risk & group srze below 50 \\
\hline
\end{tabular}

\section{Jia 2006}

\begin{tabular}{ll}
\hline Methods & $\begin{array}{l}\text { Randomised, double blind, double dummy, active control, parallel group. Not } \\
\text { obviously enriched } \\
\text { Duration } 14 \text { days }\end{array}$ \\
\hline Participants & $\begin{array}{l}\text { Painful peripheral diabetic neuropathy } \\
\mathrm{N}=132 \text { (66 in each treatment group) } \\
\text { Age and sex not reported }\end{array}$ \\
\hline Interventions & CBZ 100 mg twice daily \\
& Venlafaxine 25 mg twice daily \\
\hline Outcomes & Numerical pain intensity scores using 11 point Likert scale \\
& Assessment of ADL, sleep and mood \\
& Withdrawals \\
& Adverse events \\
\hline Notes & Oxford Quality Score: $\mathrm{R}=2$, DB $=2, \mathrm{~W}=1$, Total = 5 \\
\hline Risk of bias & \\
\hline Bias & Authors' judgement $\quad$ Support for judgement \\
\hline $\begin{array}{l}\text { Random sequence generation } \\
\text { (selection bias) }\end{array}$ & Low risk \\
\hline
\end{tabular}

Cochrane Database Syst Rev. Author manuscript; available in PMC 2014 September 11. 


\begin{tabular}{lll}
$\begin{array}{l}\text { Allocation concealment (selection } \\
\text { bias) }\end{array}$ & Low risk & 'sealed opaque envelopes' \\
\hline $\begin{array}{l}\text { Blinding (performance bias and } \\
\text { detection bias) } \\
\begin{array}{l}\text { Active and controlled appeared } \\
\text { similar }\end{array}\end{array}$ & Low risk & $\begin{array}{l}\text { Double dummy design. 'each patient took } \\
\text { venlafaxine 25mg plus one dummy carbamazepine' } \\
\text { or vice versa }\end{array}$ \\
\hline Duration & High risk & 14 days \\
\hline Outcome & High risk & Mean data only, no responder analysis \\
\hline Incomple outcome assessment & Unclear risk & Not stated \\
\hline Size & Unclear risk & 66 in each treatment group \\
\hline
\end{tabular}

\section{Keczkes 1980}

\begin{tabular}{|c|c|c|}
\hline Methods & \multicolumn{2}{|c|}{$\begin{array}{l}\text { Randomised, probably not blind, active control, parallel group. Duration } 4 \text { weeks. } \\
\text { Clinic follow-up until no pain (maximum > } 1 \text { year) }\end{array}$} \\
\hline Participants & \multicolumn{2}{|c|}{$\begin{array}{l}\text { Acute herpes zoster } \\
\mathrm{N}=40 \text { participants } \\
\text { All over } 50 \text { years old. Sex not reported }\end{array}$} \\
\hline Interventions & \multicolumn{2}{|c|}{$\begin{array}{l}\text { CBZ } 100 \mathrm{mg} 4 \times \text { daily } \\
\text { Prednisolone } 40 \mathrm{mg} \text { daily for } 10 \text { days then reduced to nought over next } 3 \text { weeks } \\
\text { Topical antibiotics on the lesions. Carbamazepine was regarded as a placebo by } \\
\text { the investigators } \\
\text { Free access to analgesics in the post-herpetic neuralgic phase but not in the acute } \\
\text { phase }\end{array}$} \\
\hline Outcomes & \multicolumn{2}{|c|}{ Pain, skin healing, incidence of postherpetic neuralgia (> 2 months) } \\
\hline Notes & \multicolumn{2}{|c|}{ Oxford Quality Score $\mathrm{R}=1, \mathrm{DB}=0, \mathrm{~W}=0$, Total $=1$} \\
\hline \multicolumn{3}{|l|}{ Risk of bias } \\
\hline Bias & Authors' judgement & Support for judgement \\
\hline $\begin{array}{l}\text { Random sequence generation } \\
\text { (selection bias) }\end{array}$ & Unclear risk & ‘allocated randomly’ \\
\hline $\begin{array}{l}\text { Allocation concealment (selection } \\
\text { bias) }\end{array}$ & Unclear risk & No statement \\
\hline $\begin{array}{l}\text { Blinding (performance bias and } \\
\text { detection bias) } \\
\text { Active and controlled appeared } \\
\text { similar }\end{array}$ & High risk & No statement \\
\hline Duration & Unclear risk & duration 4 weeks \\
\hline Outcome & Unclear risk & No applicable outcomes \\
\hline Incomple outcome assessment & Unclear risk & Not applicable \\
\hline Size & High risk & group size below 50 \\
\hline
\end{tabular}

Killian 1968

\begin{tabular}{ll}
\hline Methods & $\begin{array}{l}\text { Randomised, double blind, placebo controlled, partial cross-over. Duration } 10 \\
\text { days (2 5-day periods). Not obviously enriched } \\
\text { Open follow-up, range } 2 \text { weeks to } 36 \text { months }\end{array}$ \\
\hline Participants & $\begin{array}{l}\text { Trigeminal neuralgia } \\
\mathrm{N}=30 . \mathrm{PHN}, \mathrm{n}=6, \text { other chronic neuralgia, } \mathrm{n}=6 .\end{array}$
\end{tabular}

Cochrane Database Syst Rev. Author manuscript; available in PMC 2014 September 11. 
36 of 42 participants studied double blind ( 24 of 32 with TN)

Age range 36 to 83 (mean 52) years, Female 66\%

\begin{tabular}{|c|c|c|}
\hline Interventions & \multicolumn{2}{|c|}{$\begin{array}{l}\text { Carbamazepine dose titration } 400 \mathrm{mg} \text { to } 1 \mathrm{~g} \text { daily } \\
\text { Placebo }\end{array}$} \\
\hline Outcomes & \multicolumn{2}{|c|}{$\begin{array}{l}\text { Complete or very good pain response } \\
\text { Withdrawals } \\
\text { Adverse events }\end{array}$} \\
\hline Notes & \multicolumn{2}{|c|}{$\begin{array}{l}\text { Oxford Quality Score: } \mathrm{R}=1, \mathrm{DB}=2, \mathrm{~W}=1 \text {, Total }=4 \\
\text { Geigy sponsored }\end{array}$} \\
\hline \multicolumn{3}{|l|}{ Risk of bias } \\
\hline Bias & Authors' judgement & Support for judgement \\
\hline $\begin{array}{l}\text { Random sequence generation } \\
\text { (selection bias) }\end{array}$ & Unclear risk & 'which were randomised' \\
\hline $\begin{array}{l}\text { Allocation concealment (selection } \\
\text { bias) }\end{array}$ & Unclear risk & No statement \\
\hline $\begin{array}{l}\text { Blinding (performance bias and } \\
\text { detection bias) } \\
\text { Active and controlled appeared } \\
\text { similar }\end{array}$ & Low risk & $\begin{array}{l}\text { 'a double bind technique ....consisted of } \\
\text { identical tablets' }\end{array}$ \\
\hline Duration & High risk & 5 day treatment period \\
\hline Outcome & Low risk & $\begin{array}{l}\text { Complete or very good pain response is } \\
\text { equivalent to } \geq 50 \% \text { pain relief }\end{array}$ \\
\hline Incomple outcome assessment & Unclear risk & Not stated \\
\hline Size & High risk & groups size below 50 \\
\hline
\end{tabular}

Lechin 1989

\begin{tabular}{|c|c|}
\hline Methods & $\begin{array}{l}\text { Multicentre (4), randomised, double blind, active control, cross-over. Duration } 24 \\
\text { weeks ( } 4 \text { week run-in, then two 8-week periods with 4-week washout). Not } \\
\text { enriched } \\
\text { Open follow up on pimozide. }\end{array}$ \\
\hline Participants & $\begin{array}{l}\text { Trigeminal neuralgia. Duration of illness } 8-17 \text { (median } 13.2 \text { ) years } \\
\mathrm{N}=59 \text { randomised. Only } 48 \text { evaluated due to protocol violation and dropout } \\
\text { Age } 48 \text { to } 64 \text { (mean 59.3) years. Male } 24 \text {, Female } 24\end{array}$ \\
\hline Interventions & $\begin{array}{l}\text { CBZ } 300 \text { to } 1200 \mathrm{mg} \text { daily in } 2 \text { divided doses } \\
\text { Pimozide } 4 \text { to } 12 \mathrm{mg} \text { daily in } 2 \text { divided doses } \\
\text { Step titration with daily doses as follows: CBZ and pimozide, days } 1 \text { to } 4300 \mathrm{mg} \\
\text { and } 4 \mathrm{mg} \text { respectively; days } 5 \text { to } 9600 \mathrm{mg} \text { and } 6 \mathrm{mg} \text { respectively; days } 10 \text { to } 14 \text {, } \\
900 \mathrm{mg} \text { and } 8 \mathrm{mg} \text { respectively; day } 15 \text { to end of treatment, } 1200 \mathrm{mg} \text { and } 12 \mathrm{mg} \\
\text { respectively }\end{array}$ \\
\hline Outcomes & $\begin{array}{l}\text { TN symptom score } \\
\text { Adverse events }\end{array}$ \\
\hline Notes & $\begin{array}{l}\text { Oxford Quality Score: } \mathrm{R}=1, \mathrm{DB}=2, \mathrm{~W}=1 \text {, Total }=4 \\
\text { Grant from Foundation of the institute for Experimental Medicine }\end{array}$ \\
\hline \multicolumn{2}{|l|}{ Risk of bias } \\
\hline Bias & Support for judgement \\
\hline $\begin{array}{l}\text { Random sequence generation } \\
\text { (selection bias) }\end{array}$ & $\begin{array}{l}\text { 'patients were randomly distributed in two } \\
\text { groups' }\end{array}$ \\
\hline $\begin{array}{l}\text { Allocation concealment } \\
\text { (selection bias) }\end{array}$ & Unclear risk \\
\hline $\begin{array}{l}\text { Blinding (performance bias and } \\
\text { detection bias) }\end{array}$ & $\begin{array}{l}\text { 'all medications were administered in } \\
\text { identical dark capsules' }\end{array}$ \\
\hline
\end{tabular}

Cochrane Database Syst Rev. Author manuscript; available in PMC 2014 September 11. 
Active and controlled appeared

similar

\begin{tabular}{lll}
\hline Duration & Low risk & 8 weeks treatment \\
\hline Outcome & High risk & Average pain score \\
\hline Incomple outcome assessment & Unclear risk & Not stated \\
\hline Size & High risk & group size below 50 \\
\hline
\end{tabular}

Leijon 1989

\begin{tabular}{|c|c|c|}
\hline Methods & \multicolumn{2}{|c|}{$\begin{array}{l}\text { Randomised, double blind, double dummy, active control, cross-over. Duration } 14 \\
\text { weeks (three } 4 \text {-week periods with two one-week washouts). No follow up. } \\
\text { Partially enriched }\end{array}$} \\
\hline Participants & \multicolumn{2}{|c|}{$\begin{array}{l}\text { Central post stroke pain } \\
\mathrm{N}=15 \\
\text { Age not reported, Male } 12 \text {, Female } 3\end{array}$} \\
\hline Interventions & \multicolumn{2}{|c|}{$\begin{array}{l}\text { Stepped increase to final dose of CBZ } 800 \mathrm{mg} \text { daily starting at } 100 \mathrm{mg} 2 \times \text { daily on } \\
\text { day } 1 \text { then increasing on days } 2,6,15,18 \\
\text { Stepped increase to final daily dose of amitriptyline of } 25 \mathrm{mg} \text { in the morning and } \\
50 \mathrm{mg} \text { at night, starting at } 12.5 \mathrm{mg} 2 \mathrm{x} \text { daily on day } 1 \text { then increasing on days } 2,6 \text {, } \\
15,18\end{array}$} \\
\hline Outcomes & \multicolumn{2}{|c|}{$\begin{array}{l}\text { Daily pain intensity (10 step verbal scale), post treatment global rating } \\
\text { Withdrawals }\end{array}$} \\
\hline Notes & \multicolumn{2}{|c|}{$\begin{array}{l}\text { Oxford Quality Score: } \mathrm{R}=1, \mathrm{DB}=2, \mathrm{~W}=1 \text {, Total }=4 \\
\text { Sponsorship - Swedish public funds }\end{array}$} \\
\hline \multicolumn{3}{|l|}{ Risk of bias } \\
\hline Bias & Authors' judgement & Support for judgement \\
\hline $\begin{array}{l}\text { Random sequence generation } \\
\text { (selection bias) }\end{array}$ & Unclear risk & 'treatment given in randomised order' \\
\hline $\begin{array}{l}\text { Allocation concealment } \\
\text { (selection bias) }\end{array}$ & Unclear risk & Not stated \\
\hline $\begin{array}{l}\text { Blinding (performance bias and } \\
\text { detection bias) } \\
\text { Active and controlled appeared } \\
\text { similar }\end{array}$ & Low risk & $\begin{array}{l}\text { 'identical capsules containing active drug } \\
\text { or lactulose(!) were give in double dummy } \\
\text { technique' }\end{array}$ \\
\hline Duration & Unclear risk & 4 week treatment periods \\
\hline Outcome & Low risk & Individual pain response levels shown \\
\hline Incomple outcome assessment & Unclear risk & Not stated \\
\hline Size & High risk & group size below 50 \\
\hline
\end{tabular}

Lindstrom 1987

\begin{tabular}{ll}
\hline Methods & $\begin{array}{l}\text { Randomised, double blind, active control, cross-over (two 2 week periods - } \\
\text { washout?). } \\
\text { No follow up. Not enriched }\end{array}$ \\
\hline Participants & Trigeminal neuralgia. $\mathrm{N}=12$ \\
& Age $41-78$ years. Male 5, Female 7. \\
\hline Interventions & CBZ to maximum tolerated dose \\
& Tocainide $20 \mathrm{mg} / \mathrm{kg}$ in 3 divided daily doses. Actual doses not reported \\
\hline
\end{tabular}

Cochrane Database Syst Rev. Author manuscript; available in PMC 2014 September 11. 


\begin{tabular}{|c|c|c|}
\hline Outcomes & \multicolumn{2}{|c|}{$\mathrm{TN}$ score consisted of severity, frequency and duration of attacks } \\
\hline Notes & \multicolumn{2}{|c|}{$\begin{array}{l}\text { Oxford Quality Score: } \mathrm{R}=1, \mathrm{DB}=1, \mathrm{~W}=0 \text {, Total }=2 \\
\text { Sponsored by Folsam Research Foundaton, Vivian L Smith Foundation }\end{array}$} \\
\hline \multicolumn{3}{|l|}{ Risk of bias } \\
\hline Bias & Authors' judgement & Support for judgement \\
\hline $\begin{array}{l}\text { Random sequence generation } \\
\text { (selection bias) }\end{array}$ & Unclear risk & 'randomised double blind technique' \\
\hline $\begin{array}{l}\text { Allocation concealment (selection } \\
\text { bias) }\end{array}$ & Unclear risk & Not stated \\
\hline $\begin{array}{l}\text { Blinding (performance bias and } \\
\text { detection bias) } \\
\text { Active and controlled appeared } \\
\text { similar }\end{array}$ & Unclear risk & $\begin{array}{l}\text { Stated as double blind but no further } \\
\text { information }\end{array}$ \\
\hline Duration & High risk & 2 week treatment \\
\hline Outcome & Low risk & Individual start and end pain scores given \\
\hline Incomple outcome assessment & Unclear risk & Not stated \\
\hline Size & High risk & group size below 50 \\
\hline
\end{tabular}

Nicol 1969

\begin{tabular}{|c|c|c|}
\hline Methods & \multicolumn{2}{|c|}{$\begin{array}{l}\text { Randomised, double blind, placebo controlled, partial crossover (successful first } \\
\text { treatment period stayed on same treatment). Duration of treatment } 2-42 \text { months. } \\
\text { Not obviously enriched } \\
\text { Follow up } 46 \text { months. }\end{array}$} \\
\hline Participants & \multicolumn{2}{|c|}{$\begin{array}{l}\text { Facial pain } \\
\mathrm{N}=64,54 \text { with trigeminal neuralgia. } \\
\text { Results presented on } 44 \mathrm{TN} \text { only, due to insufficient follow up } \\
\text { Age not given. Male } 21 \text {, Female } 23\end{array}$} \\
\hline Interventions & \multicolumn{2}{|c|}{$\begin{array}{l}\text { CBZ dose titration } 100 \mathrm{mg} \text { to } 2.4 \mathrm{~g} \text { daily } \\
\text { Placebo } \\
\text { Participants started on one treatment and increased dose to } 8 \text { tablets daily. At two } \\
\text { weeks, if no satisfactory results, the second treatment was substituted } \\
20 \text { had carbamazepine only, } 7 \text { had placebo only. } 17 \text { had placebo then } \\
\text { carbamazepine }\end{array}$} \\
\hline Outcomes & \multicolumn{2}{|l|}{ Withdrawals } \\
\hline Notes & \multicolumn{2}{|c|}{$\begin{array}{l}\text { Oxford Quality Score: } \mathrm{R}=1, \mathrm{DB}=1, \mathrm{~W}=1 \text {, Total }=3 \\
\text { Geighy supplied the tablets }\end{array}$} \\
\hline \multicolumn{3}{|l|}{ Risk of bias } \\
\hline Bias & Authors' judgement & Support for judgement \\
\hline $\begin{array}{l}\text { Random sequence generation } \\
\text { (selection bias) }\end{array}$ & Unclear risk & 'randomised investigation' \\
\hline $\begin{array}{l}\text { Allocation concealment } \\
\text { (selection bias) }\end{array}$ & Unclear risk & Not stated \\
\hline $\begin{array}{l}\text { Blinding (performance bias and } \\
\text { detection bias) } \\
\text { Active and controlled appeared } \\
\text { similar }\end{array}$ & Unclear risk & $\begin{array}{l}\text { Stated as double blind but no further } \\
\text { information }\end{array}$ \\
\hline Duration & Low risk & long duration $\geq 12$ weeks \\
\hline Outcome & Unclear risk & $\begin{array}{l}\text { Probable that response was equivalent to } \geq \\
30 \% \text { pain relief }\end{array}$ \\
\hline
\end{tabular}

Cochrane Database Syst Rev. Author manuscript; available in PMC 2014 September 11. 


\begin{tabular}{lll} 
Incomple outcome assessment & Unclear risk & Not stated \\
\hline Size & High risk & $\begin{array}{l}\text { Partial crossover means that groups size } \\
\text { was below 50 }\end{array}$ \\
\hline
\end{tabular}

\section{Rasmussen 1970}

\begin{tabular}{|c|c|c|}
\hline Methods & \multicolumn{2}{|c|}{$\begin{array}{l}\text { Single blind, placebo controlled, cross-over study based on drawn lots (three 5- } \\
\text { day periods as either active-placebo-active or placebo-active-placebo). Partial } \\
\text { enrichment, participants who had previously received carbamazepine were } \\
\text { excluded }\end{array}$} \\
\hline Participants & \multicolumn{2}{|c|}{$\begin{array}{l}\text { Facial pain divided into } 3 \text { groups: typical trigeminal neuralgia, } \mathrm{n}=40 \text {, atypical } \\
\text { trigeminal neuralgia, } \mathrm{n}=16 \text {, non neuralgiform, } \mathrm{n}=15 \\
\text { Total } \mathrm{N}=71 \\
80 \% \text { aged over } 60 \text { years. Sex not reported }\end{array}$} \\
\hline Interventions & \multicolumn{2}{|c|}{$\begin{array}{l}\text { CBZ } 1 \text { tablet } 2 \text { or } 3 x \text { daily. Actual dose not stated. Assumed to be } 200 \mathrm{mg} \text { tablets } \\
\text { Placebo }\end{array}$} \\
\hline Outcomes & \multicolumn{2}{|c|}{$\begin{array}{l}\text { 'Good effect' not clearly defined. } \\
\text { Withdrawals } \\
\text { Adverse events }\end{array}$} \\
\hline Notes & \multicolumn{2}{|c|}{ Oxford Quality Score: $\mathrm{R}=1, \mathrm{DB}=0, \mathrm{~W}=1$, Total $=2$} \\
\hline \multicolumn{3}{|l|}{ Risk of bias } \\
\hline Bias & Authors' judgement & Support for judgement \\
\hline $\begin{array}{l}\text { Random sequence generation } \\
\text { (selection bias) }\end{array}$ & Unclear risk & 'Lots were drawn' \\
\hline $\begin{array}{l}\text { Allocation concealment (selection } \\
\text { bias) }\end{array}$ & High risk & $\begin{array}{l}\text { Statement that authors were aware of the } \\
\text { code }\end{array}$ \\
\hline $\begin{array}{l}\text { Blinding (performance bias and } \\
\text { detection bias) } \\
\text { Active and controlled appeared } \\
\text { similar }\end{array}$ & High risk & $\begin{array}{l}\text { Statement that authors were aware of the } \\
\text { code }\end{array}$ \\
\hline Duration & High risk & 5 day treatment period \\
\hline Outcome & High risk & no definition \\
\hline Incomple outcome assessment & Unclear risk & Not stated \\
\hline Size & Unclear risk & group size over 50 in crossover study \\
\hline
\end{tabular}

Rockliff 1966

\begin{tabular}{ll}
\hline Methods & $\begin{array}{l}\text { Randomised, double blind, placebo controlled, cross-over. Duration two 3-day } \\
\text { periods. } \\
\text { No washout. Not obviously enriched }\end{array}$ \\
\hline Participants & $\begin{array}{l}\text { Trigeminal neuralgia. Duration of illness } 2 \text { weeks to } 30 \text { years } \\
\mathrm{N}=9 \\
\text { Mean age } 65(37-81) \text { years. Male } 1 \text { Female } 8\end{array}$ \\
\hline Interventions & Carbamazepine 200 mg or placebo $3 x$ daily for 3 days, then crossover \\
\hline Outcomes & \\
\hline Notes & Oxford Quality Score: $\mathrm{R}=1, \mathrm{DB}=2, \mathrm{~W}=1$, Total $=1$ \\
\hline Risk of bias & Geigy supplied the tablets \\
\hline
\end{tabular}

Cochrane Database Syst Rev. Author manuscript; available in PMC 2014 September 11. 


\begin{tabular}{|c|c|c|}
\hline Bias & Authors' judgement & Support for judgement \\
\hline $\begin{array}{l}\text { Random sequence generation } \\
\text { (selection bias) }\end{array}$ & Unclear risk & 'the sequence as pre-randomised' \\
\hline $\begin{array}{l}\text { Allocation concealment (selection } \\
\text { bias) }\end{array}$ & Unclear risk & Not stated \\
\hline $\begin{array}{l}\text { Blinding (performance bias and } \\
\text { detection bias) } \\
\text { Active and controlled appeared } \\
\text { similar }\end{array}$ & Low risk & 'similar appearing tablets were given' \\
\hline Duration & High risk & 3 days treatment \\
\hline Outcome & High risk & Preference rather than level of pain relief \\
\hline Incomple outcome assessment & Unclear risk & Not stated \\
\hline Size & High risk & group size below 50 \\
\hline
\end{tabular}

Rull 1969

\begin{tabular}{|c|c|c|}
\hline Methods & \multicolumn{2}{|c|}{$\begin{array}{l}\text { Randomised, double blind, placebo-controlled, cross-over. Duration } 6 \text { weeks } \\
\text { (three } 2 \text {-week periods), no follow-up. Not obviously enriched }\end{array}$} \\
\hline Participants & \multicolumn{2}{|c|}{$\begin{array}{l}\text { Diabetic neuropathy } \\
\mathrm{N}=30 \\
\text { Mean age } 54(21-81) \text { years. Male } 21 \text {, Female } 30\end{array}$} \\
\hline Interventions & \multicolumn{2}{|c|}{$\begin{array}{l}\text { CBZ } 200 \mathrm{mg} \text { to } 600 \mathrm{mg} \text { daily } \\
\text { Placebo } \\
\text { Sequence CBZ, P, CBZ or P, CBZ, P }\end{array}$} \\
\hline Outcomes & \multicolumn{2}{|l|}{ Adverse events } \\
\hline Notes & \multicolumn{2}{|c|}{ Oxford Quality Score: $\mathrm{R}=1, \mathrm{DB}=2, \mathrm{~W}=1$, Total $=4$} \\
\hline \multicolumn{3}{|l|}{ Risk of bias } \\
\hline Bias & Authors' judgement & Support for judgement \\
\hline $\begin{array}{l}\text { Random sequence generation } \\
\text { (selection bias) }\end{array}$ & Unclear risk & $\begin{array}{l}\text { 'on a random basis, individuals were } \\
\text { assigned' }\end{array}$ \\
\hline $\begin{array}{l}\text { Allocation concealment (selection } \\
\text { bias) }\end{array}$ & Unclear risk & Not stated \\
\hline $\begin{array}{l}\text { Blinding (performance bias and } \\
\text { detection bias) } \\
\text { Active and controlled appeared } \\
\text { similar }\end{array}$ & Low risk & 'both drug and placebo were identical' \\
\hline Duration & High risk & 2 week treatment period \\
\hline Outcome & Low risk & individual patient level results available \\
\hline Incomple outcome assessment & Unclear risk & Not stated \\
\hline Size & High risk & Group size below 50 \\
\hline
\end{tabular}

\section{Vilming 1986}

\begin{tabular}{ll}
\hline Methods & $\begin{array}{l}\text { Randomised, double blind, active control, parallel group. } 3 \text { weeks, no follow } \\
\text { up. Not obviously enriched }\end{array}$ \\
\hline Participants & Trigeminal neuralgia. $\mathrm{N}=12$. Age range 47-72 years \\
\hline
\end{tabular}

Cochrane Database Syst Rev. Author manuscript; available in PMC 2014 September 11. 
Interventions

\begin{tabular}{|c|c|c|}
\hline Outcomes & \multicolumn{2}{|c|}{ Pain intensity, pain relief, global assessment } \\
\hline Notes & \multicolumn{2}{|c|}{ Oxford Quality Score: $\mathrm{R}=1, \mathrm{DB}=1, \mathrm{~W}=1$, Total $=3$} \\
\hline \multicolumn{3}{|l|}{ Risk of bias } \\
\hline Bias & Authors' judgement & Support for judgement \\
\hline $\begin{array}{l}\text { Random sequence generation } \\
\text { (selection bias) }\end{array}$ & Unclear risk & 'randomly allocated' \\
\hline $\begin{array}{l}\text { Allocation concealment (selection } \\
\text { bias) }\end{array}$ & Unclear risk & Not stated \\
\hline $\begin{array}{l}\text { Blinding (performance bias and } \\
\text { detection bias) } \\
\text { Active and controlled appeared } \\
\text { similar }\end{array}$ & Unclear risk & Stated as double blind but no further information \\
\hline Duration & Unclear risk & 3 week treatment period \\
\hline Outcome & Low risk & $\begin{array}{l}\text { Number with various grades of pain relief, } \\
\text { including very good by patient }\end{array}$ \\
\hline Incomple outcome assessment & Unclear risk & Not stated \\
\hline Size & High risk & Group size below 50 \\
\hline
\end{tabular}

\section{Wilton 1974}

\begin{tabular}{|c|c|c|}
\hline Methods & \multicolumn{2}{|c|}{$\begin{array}{l}\text { Randomised, double blind, placebo controlled, cross-over. Duration } 4 \text { weeks: } 2 \text { - } \\
\text { week washout then } 7 \text { days on each treatment period. No washout between } \\
\text { treatments }\end{array}$} \\
\hline Participants & \multicolumn{2}{|c|}{$\begin{array}{l}\text { Diabetic neuropathy of at least } 3 \text { months. } \\
N=40 \\
\text { Mean age } 56 \text { (range } 28-70 \text { ) years. Female } 75 \%\end{array}$} \\
\hline Interventions & \multicolumn{2}{|c|}{$\begin{array}{l}\text { Carbamazepine } 200 \mathrm{mg} 3 \times \text { daily } \\
\text { Placebo }\end{array}$} \\
\hline Outcomes & \multicolumn{2}{|c|}{$\begin{array}{l}\text { Patient reported pain: } 10 \mathrm{~cm} \text { VAS scale. } \\
\text { Reported numbness, agitation, ability to sleep, depression and anxiety }\end{array}$} \\
\hline Notes & \multicolumn{2}{|c|}{$\begin{array}{l}\text { Oxford Quality Score: } \mathrm{R}=1, \mathrm{DB}=1, \mathrm{~W}=0, \text { Total }=2 \\
\text { Geighy gave assistance }\end{array}$} \\
\hline \multicolumn{3}{|l|}{ Risk of bias } \\
\hline Bias & Authors' judgement & Support for judgement \\
\hline $\begin{array}{l}\text { Random sequence generation } \\
\text { (selection bias) }\end{array}$ & Unclear risk & $\begin{array}{l}\text { 'according to a pre-randomised balanced } \\
\text { sequence' }\end{array}$ \\
\hline $\begin{array}{l}\text { Allocation concealment (selection } \\
\text { bias) }\end{array}$ & Unclear risk & Not stated \\
\hline $\begin{array}{l}\text { Blinding (performance bias and } \\
\text { detection bias) } \\
\text { Active and controlled appeared } \\
\text { similar }\end{array}$ & Low risk & 'tegretol and an identical placebo dosage' \\
\hline Duration & High risk & 7 days treatment period \\
\hline Outcome & High risk & Mean pain scores \\
\hline Incomple outcome assessment & Unclear risk & Not stated \\
\hline Size & High risk & Group size below 50 \\
\hline
\end{tabular}

Cochrane Database Syst Rev. Author manuscript; available in PMC 2014 September 11. 

ADL - activities of daily living
ADR - adverse drug reactions
$\mathrm{AE}$ - adverse effects
CBZ- carbamazepine
$\mathrm{TN}$ - Trigeminal neuralgia
DN - diabetic neuropathy
NSAIDs - non steroidal anti-inflammatory drugs
vs - versus
SE - side effect
ADR - adverse drug reaction
QS - quality score

\section{Characteristics of excluded studies [ordered by study ID]}

\begin{tabular}{ll}
\hline Study & Reason for exclusion \\
\hline Crill 1973 & Review \\
\hline Erzurumlu 1995 & Not RCT \\
\hline Harke 2001 & RCT but required pretreatment with spinal cord stimulation. 8 days treatment \\
\hline Kudoh 1998 & Not RCT \\
\hline Lloyd-Smith 1969 & Not randomised. Some patients crossed to placebo without consent \\
\hline Swerdlow 1981 & Case series \\
\hline Swerdlow 1984 & Review \\
\hline
\end{tabular}

Characteristics of studies awaiting assessment [ordered by study ID] Badran 1975

\begin{tabular}{ll}
\hline Methods \\
\hline Participants \\
\hline Interventions \\
\hline Outcomes \\
\hline Notes $\quad$ Unable to locate paper \\
\hline
\end{tabular}

Liebel 2001

\begin{tabular}{ll}
\hline Methods \\
\hline Participants \\
\hline Interventions \\
\hline Outcomes & \\
\hline Notes & Unable to locate paper \\
\hline
\end{tabular}


DATA AND ANALYSES

\section{Comparison 1}

Carbamazepine in neuropathic pain

\begin{tabular}{|c|c|c|c|c|}
\hline Outcome or subgroup title & No. of studies & No. of participants & Statistical method & Effect size \\
\hline 1 Any pain improvement & 5 & 298 & $\begin{array}{l}\text { Risk Ratio (M-H, Fixed, } \\
95 \% \mathrm{CI})\end{array}$ & $6.13[3.89,9.65]$ \\
\hline 1.1 Trigeminal neuralgia & 3 & 208 & $\begin{array}{l}\text { Risk Ratio (M-H, Fixed, } \\
95 \% \mathrm{CI})\end{array}$ & $5.87[3.58,9.61]$ \\
\hline $\begin{array}{l}1.2 \text { Painful diabetic } \\
\text { neuropathy }\end{array}$ & 1 & 60 & $\begin{array}{l}\text { Risk Ratio (M-H, Fixed, } \\
95 \% \mathrm{CI})\end{array}$ & $8.5[2.15,33.62]$ \\
\hline 1.3 Central post stroke pain & 1 & 30 & $\begin{array}{l}\text { Risk Ratio (M-H, Fixed, } \\
95 \% \mathrm{CI})\end{array}$ & $5.0[0.66,37.85]$ \\
\hline 2 At least 1 adverse event & 4 & 346 & $\begin{array}{c}\text { Risk Ratio (M-H, Fixed, } \\
95 \% \text { CI) }\end{array}$ & $2.40[1.85,3.12]$ \\
\hline
\end{tabular}

\section{Analysis 1.1. Comparison 1 Carbamazepine in neuropathic pain, Outcome 1 Any pain improvement}

Review: Carbamazepine for acute and chronic pain in adults

Comparison: 1 Carbamazepine in neuropathic pain

Outcome: 1 Any pain improvement

\begin{tabular}{|c|c|c|c|c|c|}
\hline \multirow{2}{*}{$\begin{array}{l}\text { Study or subgroup } \\
\text { I Trigeminal neuralgia }\end{array}$} & $\begin{array}{r}\text { Carbamazepine } \\
n / N\end{array}$ & $\begin{array}{r}\text { Placebo } \\
\mathrm{n} / \mathrm{N}\end{array}$ & $\begin{array}{c}\text { Risk Ratio } \\
\text { M-H,Fixed,95\% Cl }\end{array}$ & Weight & $\begin{array}{r}\text { Risk Ratio } \\
\text { M-H,Fixed,95\% CI } \\
\end{array}$ \\
\hline & & & & & \\
\hline Nicol 1969 & 15/20 & $6 / 24$ & $=$ & $32.2 \%$ & $3.00[1.43,6.27]$ \\
\hline Rasmussen 1970 & $46 / 55$ & 8/55 & $=$ & $47.2 \%$ & $5.75[3.00,11.03]$ \\
\hline Killian 1968 & 19/27 & 0/27 & $\longrightarrow$ & $29 \%$ & $39.00[2.47,614.85]$ \\
\hline Subtotal $(95 \% \mathrm{CI})$ & 102 & 106 & - & $82.3 \%$ & $5.87[3.58,9.61]$ \\
\hline \multicolumn{6}{|c|}{ Total events: 80 (Carbamazepine). 14 (Placebo) } \\
\hline \multicolumn{6}{|c|}{ Heterogeneity: $C h i^{2}=4.99$, of $=2(P=0.08) ; 1^{2}=60 \%$} \\
\hline \multicolumn{6}{|c|}{ Test for overall effect: $Z=7.02(P<0.00001)$} \\
\hline \multicolumn{6}{|c|}{2 Painful diabetic neuropathy } \\
\hline Rull 1969 & $17 / 30$ & 2/30 & $\rightarrow$ & $11.8 \%$ & $8.50[2.15,33.62]$ \\
\hline Subtotal $(95 \% \mathrm{CI})$ & 30 & 30 & - & $11.8 \%$ & $8.50[2.15,33.62]$ \\
\hline \multicolumn{6}{|c|}{ Total events: 17 (Carbamazepine), 2 (Placebo) } \\
\hline \multirow{2}{*}{\multicolumn{6}{|c|}{$\begin{array}{l}\text { Heterogeneity, not applicable } \\
\text { Test for overall effect: } Z=3.05(P=0.0023)\end{array}$}} \\
\hline & & & & & \\
\hline \multicolumn{6}{|l|}{3 Central post stroke pain } \\
\hline Leijon 1989 & $5 / 15$ & 1/15 & $\cdot-$ & $5.9 \%$ & $5.00[0.66,37.85]$ \\
\hline
\end{tabular}




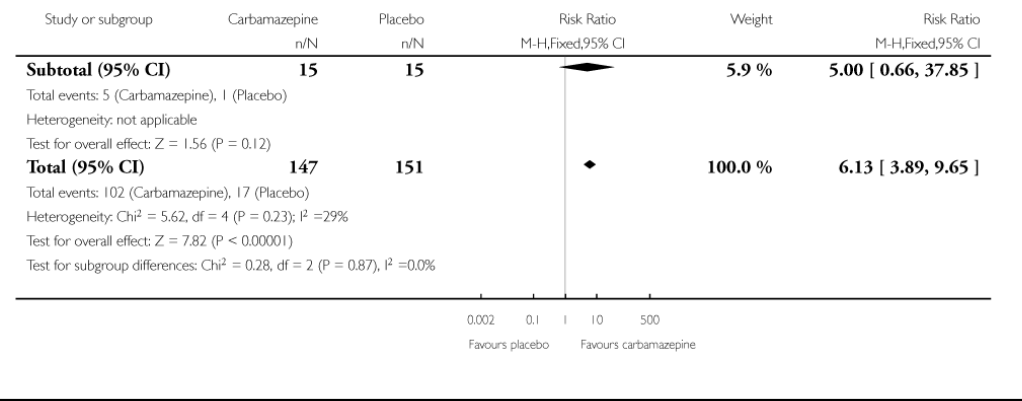

\section{Analysis 1.2. Comparison 1 Carbamazepine in neuropathic pain, Outcome 2 At least 1 adverse event}

Review: Carbamazepine for acute and chronic pain in adults

Comparison: 1 Carbamazepine in neuropathic pain

Outcome: 2 At least 1 adverse event

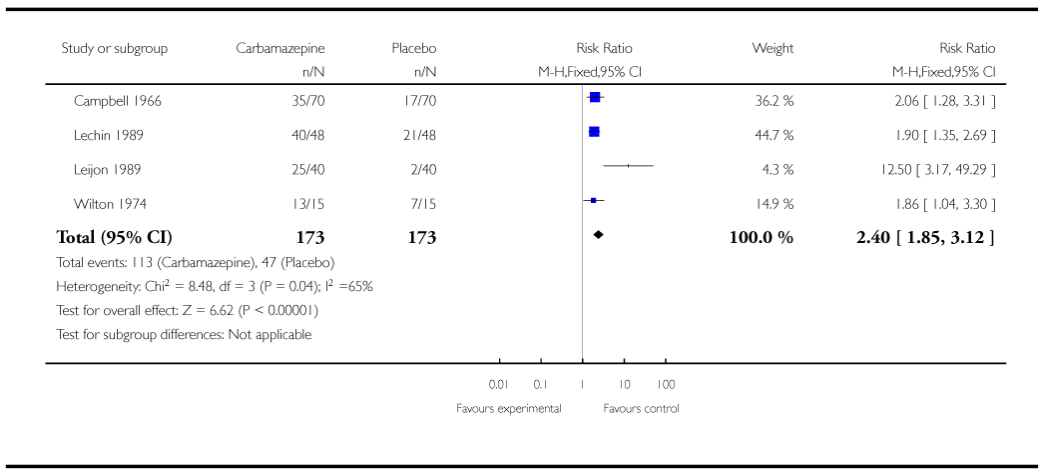

\section{Appendix 1. 1Search strategies for this update Database: Ovid MEDLINE(R) $<1950$ to 2009>}

1. (pain* or analgesi* or neuralgi* or headache* or toothache* or earache* or sciatica or causalgi* or arthralgi* or colic* or dysmenorrhoea or dysmenorrhea).mp.

[mp=title, original title, abstract, name of substance word, subject heading word] (490213)

2. (carbamazepin* or neurotol or tegretol or amizepine or epitol).mp. [mp=title, original title, abstract, name of substance word, subject heading word] (11734)

3. exp carbamazepine/ (8329)

4. 3 or $2(11734)$

5. 4 and $1(1435)$ 
6. $\left(2004 * * * *\right.$ or $2005^{* * * * *}$ or $2006^{* * * *}$ or $2007 * * * *$ or $2008 * * * *$ or $\left.2009 * * * *\right)$.ed. (4042683)

7. 6 and $5(401)$

8. randomized controlled trial.pt. (277669)

9. controlled clinical trial.pt. (80174)

10. randomized.ab. (186996)

11. placebo.ab. (114494)

12. drug therapy.fs. (1336724)

13. randomly.ab. (135505)

14. trial.ab. (193866)

15. groups.ab. (927296)

16. or/8-15 (2446949)

17. (animals not (humans and animals)).sh. (3333937)

18. $16 \operatorname{not} 17$ (2074319)

19. 18 and 7 (259)

\section{Database: EMBASE <1980 to $2009>$}

1. (pain* or analgesi* or neuralgi* or headache* or toothache* or earache* or sciatica or causalgi* or arthralgi* or colic* or dysmenorrhoea or dysmenorrhea).mp.

[mp=title, abstract, subject headings, heading word, drug trade name, original title, device manufacturer, drug manufacturer name] (511178)

2. (carbamazepin* or neurotol or tegretol or amizepine or epitol).mp. [mp=title, abstract, subject headings, heading word, drug trade name, original title, device manufacturer, drug manufacturer name] (36636)

3. exp carbamazepine/ (36104)

4. 3 or $2(36636)$

5. 4 and 1 (7006)

6. $\left(2004^{* *}\right.$ or $2005^{* *}$ or $2006^{* *}$ or $2007 * *$ or $2008^{* *}$ or $\left.2009^{* *}\right)$.em. (3307567)

7. 6 and $5(3493)$

8. random*.ti,ab. (405268)

9. factorial*.ti,ab. (8500)

10. (crossover* or cross over* or cross-over*).ti,ab. (40175)

11. placebo*.ti,ab. (112349)

12. (doubl* adj blind*).ti,ab. (86312) 
13. (singl* adj blind*).ti,ab. (7630)

14. assign*.ti,ab. (111498)

15. allocat*.ti,ab. (35309)

16. volunteer*.ti,ab. (100932)

17. CROSSOVER PROCEDURE.sh. (21622)

18. DOUBLE-BLIND PROCEDURE.sh. (73566)

19. RANDOMIZED CONTROLLED TRIAL.sh. (172175)

20. SINGLE BLIND PROCEDURE.sh. (8418)

21. or/8-20 (676735)

22. ANIMAL/ or NONHUMAN/ or ANIMAL EXPERIMENT/ (3500786)

23. HUMAN/ (6578853)

24. 22 and 23 (552965)

25. 22 not $24(2947821)$

26. 21 not $25(589330)$

27. 7 and $26(487)$

\section{Appendix 2. Results in individual studies}


Wiffen et al.

Page 30

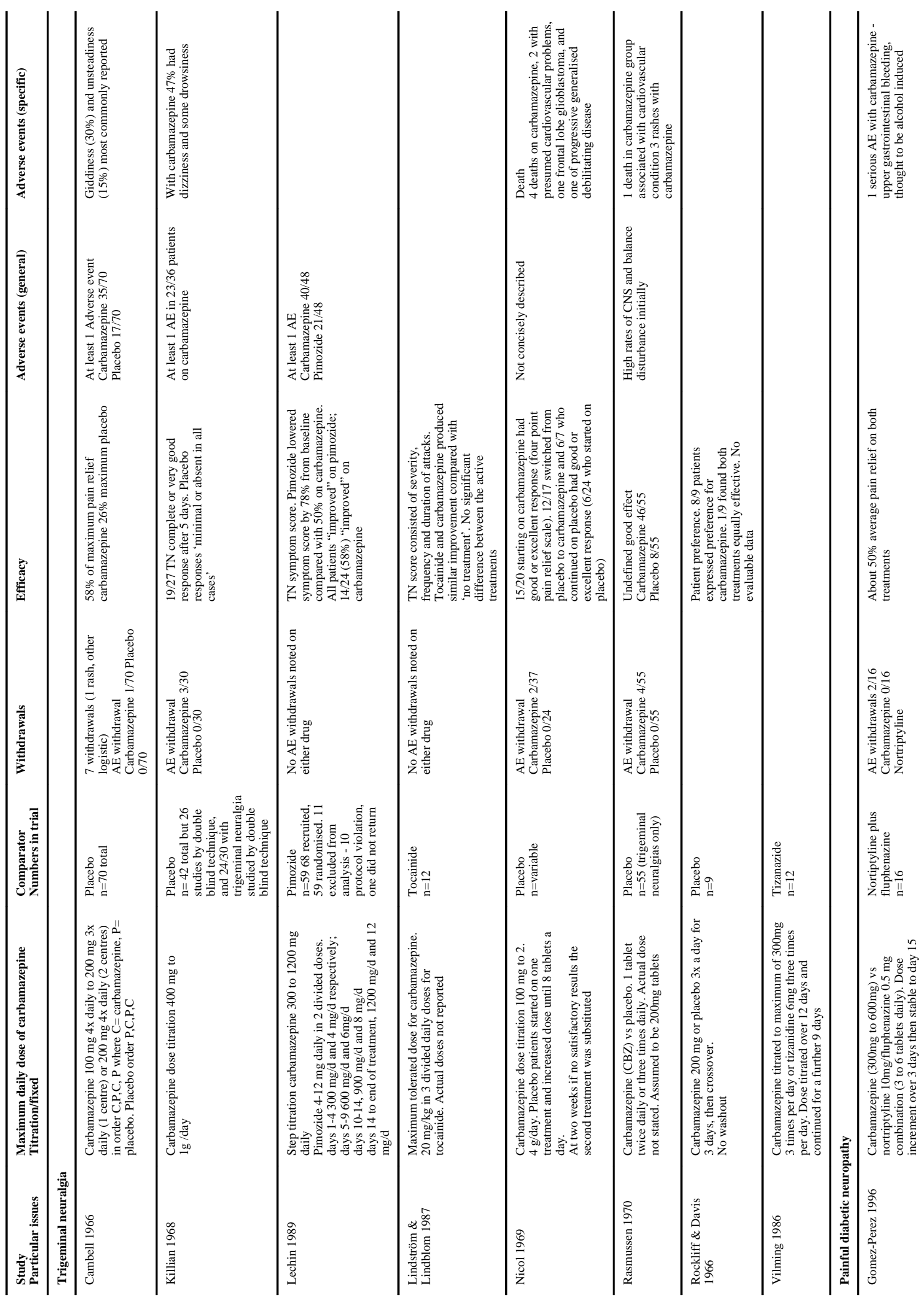

Cochrane Database Syst Rev. Author manuscript; available in PMC 2014 September 11. 
Wiffen et al.

Page 31

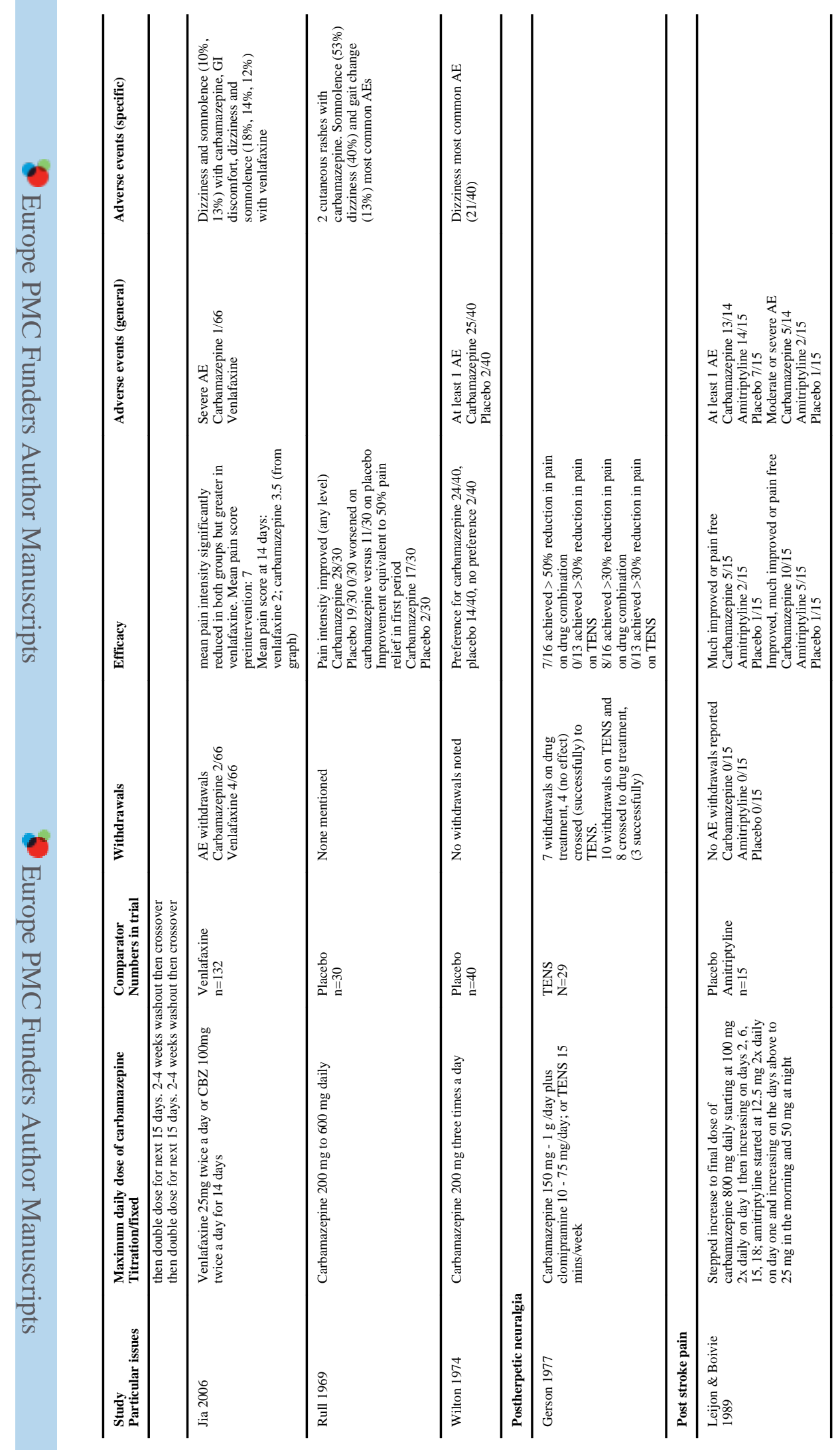

Cochrane Database Syst Rev. Author manuscript; available in PMC 2014 September 11. 


\section{HISTORY}

Review first published: Issue 3, 2005

\begin{tabular}{|c|c|c|}
\hline Date & Event & Description \\
\hline 8 February 2011 & Amended & Contact details updated. \\
\hline 8 December 2010 & $\begin{array}{l}\text { New citation } \\
\text { required but } \\
\text { conclusions } \\
\text { have not } \\
\text { changed }\end{array}$ & $\begin{array}{l}\text { This review update has been recorded for publication again as it was } \\
\text { incorrectly published previously in July } 2010 \text {. By republishing this review as a } \\
\text { new citation we would like to draw the readers' attention to the fact that this } \\
\text { review has been substantively updated with new current methods up to June } \\
2010 \text {. The conclusions on the whole remain the same, however, the } \\
\text { conclusions are now based on stronger methodology which were used to } \\
\text { analyse all results. The review byline has also changed since the original } \\
\text { publication in } 2000 \\
\text { The review was updated as follows: Review updated at first to December } 2009 \\
\text { with searches re-run in June } 2010 \text { prior to publication. There are three new } \\
\text { included studies and new parameters are considered for the chronic pain } \\
\text { studies. Results have also been reanalysed }\end{array}$ \\
\hline 8 December 2010 & Amended & $\begin{array}{l}\text { This review has been republished to draw attention to it's revised } \\
\text { methodology and more firm conclusions }\end{array}$ \\
\hline 24 September 2010 & Amended & Contact details updated. \\
\hline 1 June 2010 & $\begin{array}{l}\text { New search } \\
\text { has been } \\
\text { performed }\end{array}$ & $\begin{array}{l}\text { Review updated Dec } 2009 \text { with searches re-run in June } 2010 \text {. Three new } \\
\text { included studies. New parameters considered for chronic pain studies. Re- } \\
\text { analysis }\end{array}$ \\
\hline 27 October 2008 & Amended & $\begin{array}{l}\text { Further minor Cochrane style changes made to this review as part of RevMan } \\
5 \text { conversion process }\end{array}$ \\
\hline 7 July 2008 & Amended & Converted to new review format. \\
\hline 19 May 2005 & Amended & $\begin{array}{l}\text { This updated review on Carbamazapine was originally published as } \\
\text { Anticonvulsant drugs for acute and chronic pain. At the third update in } 2003 \text {, } \\
12 \text { new included studies were identified mainly of the newer anticonvulsants } \\
\text { gabapentin and lamotrigine. In total the included studies provided data on six } \\
\text { different medicines used in at least six identified neuropathic pain conditions. } \\
\text { Issues of dose response and trial design added to the complexity. A decision } \\
\text { was therefore taken to split this review into a number of smaller reviews each } \\
\text { covering one medicine (chemical entity) }\end{array}$ \\
\hline
\end{tabular}

\section{DIFFERENCES BETWEEN PROTOCOL AND REVIEW}

The major difference between the original protocol and this update is the concentration on issues of methodological validity and bias that have emerged subsequently - namely on size, on duration, on outcome, and potentially on a dependence on crossover designs. These are commented on and referenced in the updated review.

\section{WHAT'S NEW}

Last assessed as up-to-date: 15 September 2011.

\begin{tabular}{lll}
\hline Date & Event & Description \\
\hline 27 June 2012 & Amended & Contact details updated. \\
\hline 15 September 2011 & $\begin{array}{l}\text { Review declared as } \\
\text { stable }\end{array}$ & $\begin{array}{l}\text { The authors scanned the literature during August 2011 and were } \\
\text { confident that this review would not need updating for at least five years }\end{array}$ \\
\hline
\end{tabular}




\section{References to studies included in this review}

Campbell 1966 \{published data only\} . Campbell FG, Graham JG, Zilkha KJ. Clinical trial of carbamazepine (tegretol) in trigeminal neuralgia. Journal of Neurology, Neurosurgery \& Psychiatry. 1966; 29:265-7.

Gerson 1977 \{published data only\} . Gerson GR, Jones RB, Luscombe DK. Studies on the concomitant use of carbamazepine and clomipramine for the relief of post-herpetic neuralgia. Postgraduate Medical Journal. 1977; 53:104-9. [PubMed: 304576]

Gomez-Perez 1996 \{published data only\} . Gomez-Perez F, Choza R, Rios JM, Reza A, Huerta E, Aguilar CA, Rull JA. Nortriptyline-Fluphenazine vs Carbamazepine in the symptomatic treatment of diabetic neuropathy. Archives of Medical Research. 1996; 27(4):525-9. [PubMed: 8987189]

Jia 2006 \{published data only\} . Hai-yun, Jia; Qu-fu, Li; Dian-ping, Song; You-ping, Liu; Xingwu, Ran, et al. Effects of Venlafaxine and Carbamazepine for painful peripheral diabetic neuropathy: A randomized double blind and double dummy controlled multicenter trial. Chinese Journal of Evidence Based Medicine. 2006; 6:321-327.

Keczkes 1980 \{published data only\} . Keczkes K, Basheer AM. Do corticosteroids prevent postherpetic neuralgia? British Journal of Dermatology. 1980; 102:551-5. [PubMed: 7387900]

Killian 1968 \{published data only\}. Killian JM, Fromm GH. Carbamazepine in the treatment of neuralgia. Use and side effects. Archives of Neurology. 1968; 19:129-36. [PubMed: 4877400]

Lechin 1989 \{published data only\} . Lechin F, van der Dijs B, Lechin ME, Amat J, Lechin AE, Cabrera A, Gomez F, Acosta E, Arocha L, Villa S, Jimenez V. Pimozide therapy for trigeminal neuralgia. Archives of Neurology. 1989; 46:960-3. [PubMed: 2673161]

Leijon 1989 \{published data only\} . Leijon G, Boivie J. A controlled trial of amitriptyline and carbamazepine in central post stroke pain. Acta Nuerologica Scandanavica. 1988; 77(Suppl 116): 102.Leijon G, Boivie J. Central post-stroke pain - a controlled trial of amitriptyline and carbamazepine. Pain. 1989; 36:27-36. [PubMed: 2465530]

Lindstrom 1987 \{published data only\} . Lindstrom P, Lindblom U. The analgesic effect of tocainide in trigeminal neuralgia. Pain. 1987; 28:45-50. [DOI: 10.1016/0304-3959(87)91058-X]. [PubMed: 3103044]

Nicol 1969 \{published data only\} . Nicol CF. A four year double blind study of tegretol in facial pain. Headache. 1969; 9:54-7. [PubMed: 4896266]

Rasmussen 1970 \{published data only\} . Rasmussen P, Riishede J. Facial pain treated with carbamazepin (Tegretol). Acta Neurologica Scandinavica. 1970; 46:385-408. [PubMed: 4994082]

Rockliff 1966 \{published data only\} . Rockliff BW, Davis EH. Controlled sequential trials of Carbamazepine in trigeminal neuralgia. Archives of Neurology. 1966; 15:129-36. [PubMed: 5329617]

Rull 1969 \{published data only\} . Rull J, Quibrera R, Gonzalez-Millan H, Lozano Castenada O. Symptomatic treatment of peripheral diabetic neuropathy with carbamazepine: double-blind crossover study. Diabetologia. 1969; 5:215-20. [PubMed: 4902717]

Vilming 1986 \{published data only\} . Vilming ST, Lyberg T, Lataste X. Tizanidine in the management of trigeminal neuralgia. Cephalalgia. 1986; 6:181-2. [PubMed: 3533272]

Wilton 1974 \{published data only\} . Wilton TD. Tegretol in the Treatment of Diabetic Neuropathy. S-A Mediese Tydskrif. 1974; 48:869-872.

\section{References to studies excluded from this review}

Crill 1973 \{published data only\} . Crill WE. Carbamazepine. Annals of Internal Medicine. 1973; 79:844-7. [PubMed: 4271556]

Erzurumlu 1995 \{published data only\} . Erzurumlu A, Dursun H, Gunduz S, Kalyon T, Appacioglu O. The management of chronic pain at spinal cord injured patients [Spinal kord yarali hastalarda kronik agri tedavisi]. Romatoloji ve Tibbi Rehabilitasyon Derg. 1996; 9(3):17680 . 
Harke 2001 \{published data only\} . Harke H, Gretenkort P, Ladlief H, Rahman S, Harke Ole. The Response of Neuropathic Pain and Pain in ComplexRegional Pain Syndrome I to Carbamazepine andSustained-Release Morphine in Patients Pretreated withSpinal Cord Stimulation: A DoubleBlindedRandomized Study. Anesthesia and Analgesia. 2001; 92:488-95. [PubMed: 11159256]

Kudoh 1998 \{published data only\} . Kudoh A, Ishihara H, Matsuki A. Effect of carbamazepine on pain scores of unipolar depressed patients with chronic pain. A trial of Off-On-Off-On design. The Clinical Journal of Pain. 1998; 14(1):61-5. [PubMed: 9535315]

Lloyd-Smith 1969 \{published data only\} . Lloyd-Sith DL, Sachdev KK. A long term low doage study of carbamazepine in trigeminal neuralgia. Headache. 1969; 9:64-72. [PubMed: 4896267]

Swerdlow 1981 \{published data only\}. Swerdlow M, Cundill JG. Anticonvulsant drugs used in the treatment of lancinating pain. Anaesthesia. 1981; 36(12):1129-32. [PubMed: 6798892]

Swerdlow 1984 \{published data only\} . Swerdlow M. Anticonvulsant drugs and chronic pain. Clinical Neuropharmacology. 1984; 7(1):51-82. [PubMed: 6367974]

\section{References to studies awaiting assessment}

Badran 1975 \{published data only\} . Badran AM, Aly MA, Sous ES. A clinical trial of carbamazepine in the symptomatic treatment of diabetic peripheral neuropathy. The Journal of the Egyptian Medical Association. 1975; 58(11-12):627-631. [PubMed: 1236490]

Liebel 2001 \{published data only\} . Liebel J. Results of a double blind trial comparing oxcarbazepine vs carbamazepine in newly diagnosed, untreated patients with trigeminal neuralgia. Journal of the Neurological Sciences. 2001; 187:S5.

\section{Additional references}

Blom 1962 . Blom S. Trigeminal neuralgia: its treatment with a new anticonvulsant drug (G.32883). Lancet. 1962; 1:839-40. [PubMed: 13870089]

Chong 2000 . Chong MS, Smith TE. Anticonvulsants for the management of pain. Pain Reviews. 2000; 7:129-49.

Chung 2010 . Chung WH, Hung SI, Chen YT. Genetic predisposition of life-threatening antiepileptic-induced skin reactions. Expert Opinion on Drug Safety. 2010; 9:15-21. [PubMed: 20001755]

Colditz 1989 . Colditz GA, Miller JN, Mosteller F. How study design affects outcomes in comparisons of therapy. Statistical Methods in Medical Research. 1989; 8:441-54.

Cook 1995 . Cook RJ, Sackett DL. The number needed to treat: a clinically useful measure of treatment effect. BMJ. 1995; 310:452-4. [PubMed: 7873954]

Counsell 1994 . Counsell CE, Clarke MJ, Slattery J, Sandercock PA. The miracle of DICE therapy for acute stroke: fact or fictional product of subgroup analysis? BMJ. 1994; 309(6970):1677-81. [PubMed: 7819982]

DOH 1992 . Advisory Group on Health Technology Assessment. Assessing the Effects of Health Technologies. Department of Health; London: 1992.

Dworkin 2008 . Dworkin RH, Turk DC, Wyrwich KW, Beaton D, Cleeland CS, Farrar JT, et al. Interpreting the clinical importance of treatment outcomes in chronic pain clinical trials: IMMPACT recommendations. The Journal of Pain. 2008; 9(2):105-21. [PubMed: 18055266]

Eddy 1993 . Eddy DM. Three battles to watch in the 1990s. JAMA. 1993; 270:520-6. [PubMed: 8320794]

Elbourne 2002 . Elbourne DR, Altman DG, Higgins JP, Curtin F, Worthington HV, Vail A. Metaanalyses involving crossover trials: methodological issues. International Journal of Epidemiology. 2002; 31(1):140-9. [Online ISSN: 1464-3685; Print ISSN: 0300-5771]. [PubMed: 11914310]

Finnerup 2005 . Finnerup NB, Otto M, McQuay HJ, Jensen TS, Sindrup SH. Algorithm for neuropathic pain treatment: an evidence based proposal. Pain. 2005; 118(3):289-305. [DOI: 10.1016/j.pain.2005.08.013]. [PubMed: 16213659] 
Grahame-Smith 1992 . Grahame-Smith, DG.; Aronson, JK. Oxford Textbook of Clinical Pharmacology and Drug Therapy. 2nd Edition. Oxford University Press; Oxford: 1992. Oxford Textbook of Clinical Pharmacology and Drug Therapy.

Hall 2008 . Hall GC, Carroll D, McQuay HJ. Primary care incidence and treatment of four neuropathic pain conditions: a descriptive study, 2002-2005. BMC Family Practice. 2008; 9:26. [DOI: 10.1186/1471-2296-9-26]. [PubMed: 18460194]

Herman 2006 . Herman D, Locatelli I, Grabnar I, Peternel P, Stegnar M, Lainscak M, et al. The influence of co-treatment with carbamazepine, amiodarone and statins on warfarin metabolism and maintenance dose. European Journal of Clinical Pharmacology. 2006; 62(4):291-6. [DOI: 10.1007/s00228-006-0104-4]. [PubMed: 16552506]

Hoffman 2010 . Hoffman DL, Sadosky A, Dukes EM, Alvir J. How do changes in pain severity levels correspond to changes in health status and function in patients with painful diabetic peripheral neuropathy? Pain. 2010; 149(2):194-201. [DOI: 10.1016/j.pain.2009.09.017]. [PubMed: 20303665]

Jacox 1994 . Jacox, A.; Carr, DB.; Payne, R. Management of cancer pain. Clinical Practice Guideline No. 9. Agency for Health Care Policy and Research. US Department of Health and Human Services, Public Health Service; Rockville, Maryland: Mar. 1994 [: AHCPR Publication No. 940592]

Jadad 1994 . Jadad-Bechara, AR. Meta-analysis of randomised clinical trials in pain relief [DPhil thesis]. Balliol College, University of Oxford; Oxford: 1994.

Jadad 1996b . Jadad AR, Moore RA, Carroll D, Jenkinson C, Reynolds DJM, Gavaghan DJ, McQuay HJ. Assessing the quality of reports of randomized clinical trials: is blinding necessary? Controlled Clinical Trials. 1996; 17(1):1-12. [PubMed: 8721797]

Khan 1996 . Khan KS, Daya S, Jadad A. The importance of quality of primary studies in producing unbiased systematic reviews. Archives of Internal Medicine. 1996; 156(6):661-6. [PubMed: 8629879]

Koopman 2009 . Koopman JS, Dieleman JP, Huygen FJ, de Mos M, Martin CG, Sturkenboom MC. Incidence of facial pain in the general population. Pain. 2009; 147(1-3):122-7. [DOI: 10.1016/ j.pain.2009.08.023]. [PubMed: 19783099]

McQuay 1998 . McQuay, H.; Moore, R. An evidence-based resource for pain relief. Oxford University Press; Oxford: 1998. [: ISBN 019 263048 2]

McQuay 2007 . McQuay, HJ.; Smith, LA.; Moore, RA. Chronic Pain. In: Stevens, A.; Raftery, J.; Mant, J.; Simpson, S., editors. Health Care Needs Assessment. 3rd Edition. Radcliffe Publishing; Oxford: 2007.

McQuay 2008 . McQuay HJ, Derry S, Moore RA, Poulain P, Legout V. Enriched enrolment with randomised withdrawal (EERW): Time for a new look at clinical trial design in chronic pain. Pain. 2008; 135(3):217-20. [DOI: 10.1016/j.pain.2008.01.014]. [PubMed: 18258369]

Mehta 2009 . Mehta TY, Prajapati LM, Mittal B, Joshi CG, Sheth JJ, Patel DB, et al. Association of HLA-B*1502 allele and carbamazepine-induced Stevens-Johnson syndrome among Indians. Indian journal of dermatology, venereology and leprology. 2009; 75:579-82.

Moore 1998a . Moore RA, Gavaghan D, Tramer MR, Collins SL, McQuay HJ. Size is everything-large amounts of information are needed to overcome random effects in estimating direction and magnitude of treatment effects. Pain. 1998; 78(3):209-16. [DOI: 10.1016/ S0304-3959(98)00140-7]. [PubMed: 9870574]

Moore 1998b . Moore RA, Tramer MR, Carroll D, Wiffen PJ, McQuay HJ. Quantitative systematic review of topically applied nonsteroidal anti-inflammatory drugs. BMJ. 1998; 316(7128):333-8. [PubMed: 9487165]

Moore 2009a . Moore RA, Straube S, Wiffen PJ, Derry S, McQuay HJ. Pregabalin for acute and chronic pain in adults. Cochrane Database of Systematic Reviews. 2009; (Issue 3) [DOI: 10.1002/14651858.CD007076.pub2].

Moore 2009b . Moore RA, Moore OA, Derry S, Peloso PM, Gammaitoni AR, Wang H. Responder analysis for pain relief and numbers needed to treat in a meta-analysis of etoricoxib osteoarthritis trials: bridging a gap between clinical trials and clinical practice. Annals of the Rheumatic Diseases. Apr 12.2009 Online. [DOI: 10.1136/ard.2009.107805]. 
Moore 2009c . Moore RA, Derry S, McQuay HJ, Straube S, Aldington D, et al. for the ACTINPAIN writing group of the IASP Special Interest Group (SIG) on Systematic Reviews in Pain Relief. Clinical effectiveness: An approach to clinical trial design more relevant to clinical practice, acknowledging the importance of individual differences. Pain. Sep 10.2009 Epub ahead of print. [DOI: 10.1016/j.pain.2009.08.007].

Moore 2010a . Moore RA, Straube S, Paine J, Phillips CJ, Derry S, McQuay HJ. Fibromyalgia: Moderate and substantial pain intensity reduction predicts improvement in other outcomes and substantial quality of life gain. Pain. 2010; 149(2):360-4. [DOI: 10.1016/j.pain.2010.02.039]. [PubMed: 20347225]

Moore 2010b . Moore RA, Eccleston C, Derry S, Wiffen P, Bell RF, Straube S, et al. for the ACTINPAIN writing group of the IASP Special Interest Group (SIG) on Systematic Reviews in Pain Relief and the Cochrane Pain, Palliative and Supportive Care Systematic Review Group editors. "Evidence" in chronic pain - establishing best practice in the reporting of systematic reviews. Pain. 2010 epub ahead of print.

Rall 1992 . Rall, TW.; Schleifer, LS. Drugs effective in the therapy of the epilepsies. In: Goodman, LS.; Gilman, A.; Rall, TW.; Nies, AS.; Taylor, P., editors. The pharmacological basis of therapeutics. 8th Edition. McGraw-Hill; Toronto: 1992. p. 436-62.

Schulz 1994 . Schulz KF, Chalmers I, Hayes RJ, Altman DG. Failure to conceal treatment allocation schedules in trials influences estimates of treatment effects. Controlled Clinical Trials. 1994; 15:63-64S.

Sweetman 2005 . Sweetman, S., editor. Martindale: The Complete Drug Reference. 4th Edition. Pharmaceutical Press; London: 2005. p. 353-358.[: ISBN 085369550 4]

Tassaneeyakul 2010 . Tassaneeyakul W, Tiamkao S, Jantararoungtong T, Chen P, Lin SY, Chen WH, et al. Association between HLA-B*1502 and carbamazepine-induced severe cutaneous adverse drug reactions in a Thai population. Epilepsia. 2010; 51(5):926-30. [DOI: 10.1111/j. 1528-1167.2010.02533]. [PubMed: 20345939]

Taylor 1981 . Taylor JC, Brauer S, Espir ML. Long-term treatment of trigeminal neuralgia with carbamazepine. Postgraduate Medical Journal. 1981; 57(663):16-8. [PubMed: 7279817]

Tracey 2009 . Tracey I, Bushnell MC. How neuroimaging studies have challenged us to rethink: is chronic pain a disease? The Journal of Pain. 2009; 10(11):1113-20. [DOI: 10.1016/j.jpain. 2009.09.001]. [PubMed: 19878862]

Turner 1994 . Turner JA, Deyo RA, Loeser JD, Von Korff M, Fordyce WE. The importance of placebo effects in pain treatment and research. JAMA. 1994; 271(20):1609-14. [: ISSN 00987484]. [PubMed: 7880221]

Wiffen 2005 . Wiffen PJ, McQuay HJ, Edwards JE, Moore RA. Gabapentin for acute and chronic pain. Cochrane Database of Systematic Reviews. 2005; (Issue 3) [DOI: 10.1002/14651858.CD005452].

Wiffen 2007 . Wiffen PJ, Rees J. Lamotrigine for acute and chronic pain. Cochrane Database of Systematic Reviews. 2007; (Issue 2) [DOI: 10.1002/14651858.CD006044.pub2].

Woolf 1999 . Woolf CJ, Mannion R. Neuropathic pain, aetiology, symptoms, mechanisms, and management. Lancet. 1999; 353:1959-64. [PubMed: 10371588]

\section{References to other published versions of this review}

McQuay 1995 . McQuay HJ, Carroll D, Jadad AR, Wiffen PJ, Moore A. Anticonvulsant drugs for management of pain: a systematic review. BMJ. 1995; 311:1047-53. [PubMed: 7580659]

* Indicates the major publication for the study 


\section{PLAIN LANGUAGE SUMMARY}

\section{Carbamazepine (an anticonvulsant medicine) for acute and chronic pain}

Carbamazepine is effective for relieving chronic pain caused by damage to nerves, either from injury or disease, although the data available to support this is limited.

Anticonvulsants (also known as antiepileptics) are a group of medicines commonly used for treating 'fits' or epilepsy, but which are also effective for treating pain. The type of pain which responds well is neuropathic pain, e.g., postherpetic neuralgia (persistent pain experienced in an area previously affected by shingles), trigeminal neuralgia, and painful complications of diabetes. About two-thirds of patients who take carbamazepine for neuropathic pain can expect to achieve good pain relief in the short term, and two thirds can expect to experience at least one adverse event. 


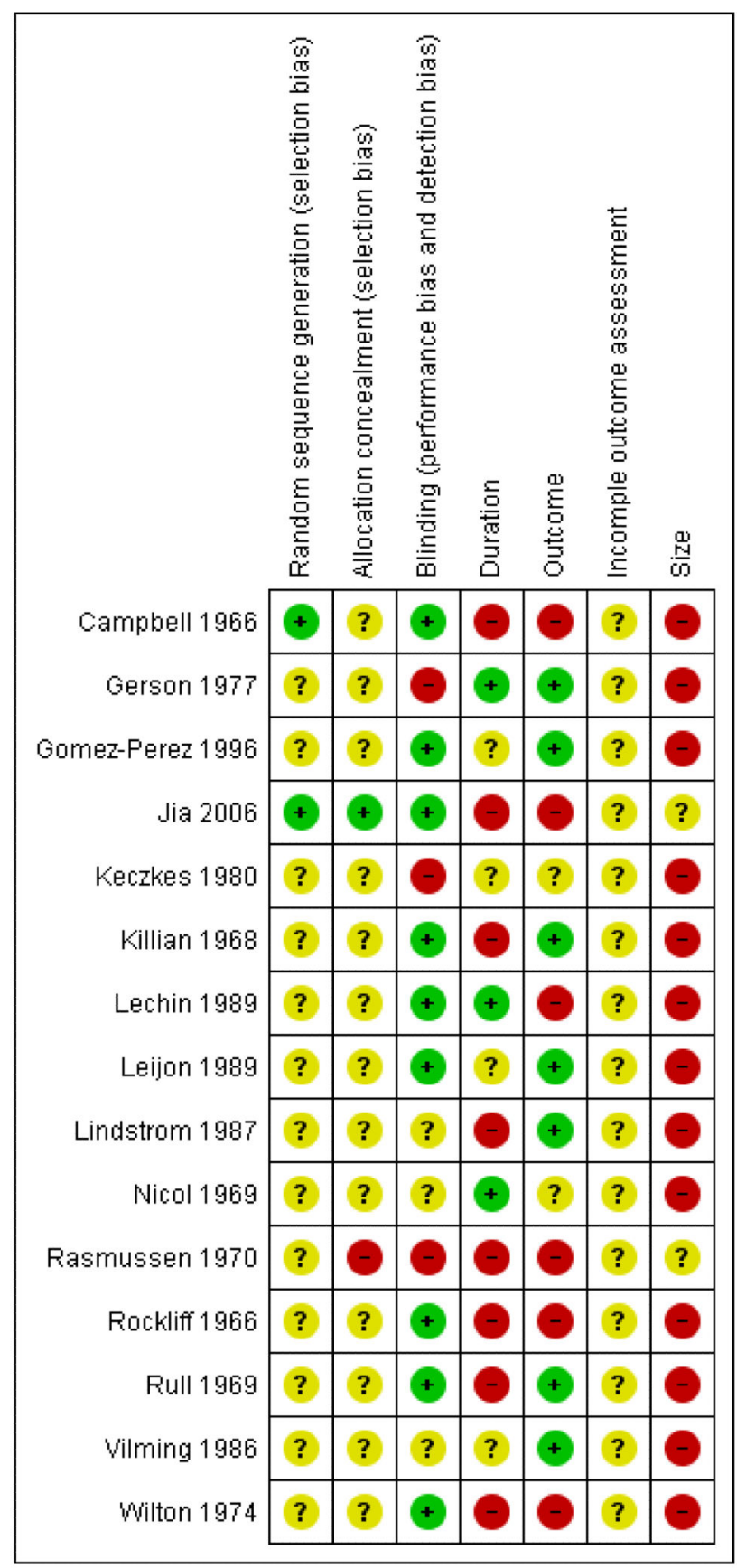

Figure 1.

Methodological quality summary: review authors' judgements about each methodological quality item for each included study. 


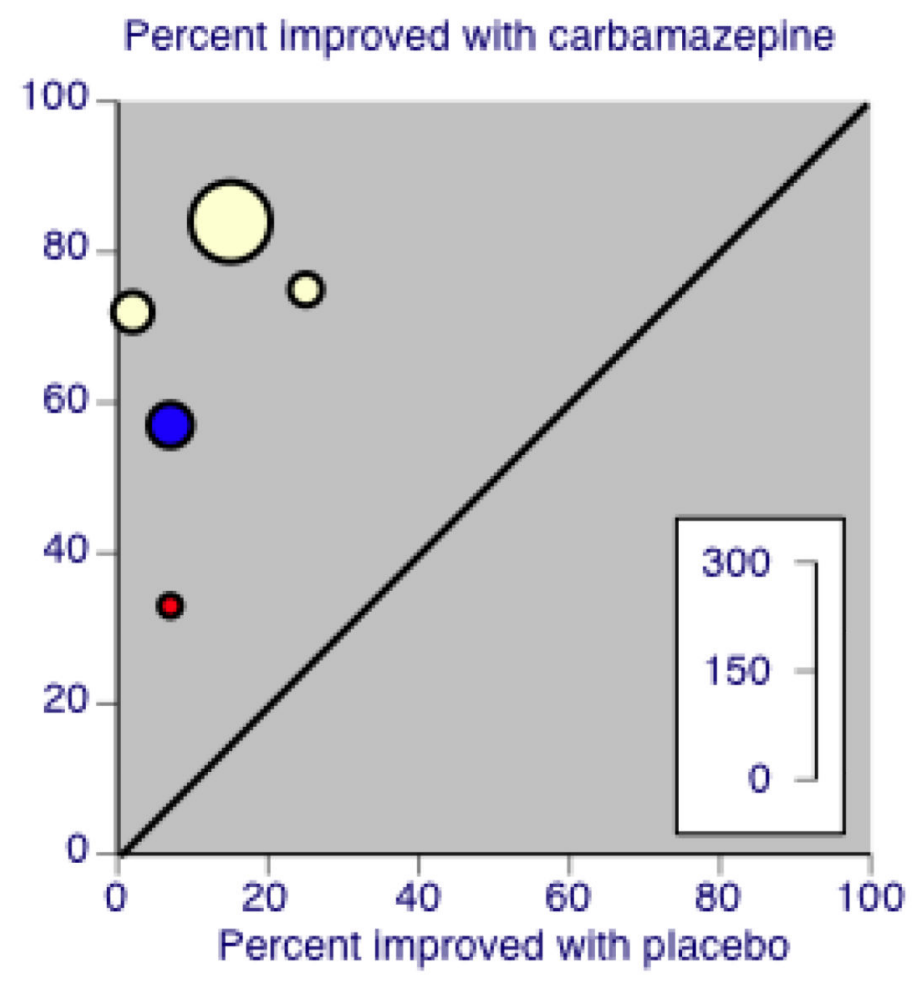

Figure 2.

Five studies showing percentage improvement (any definition) with carbamazepine (any dose) and placebo. Size of the study is proportional to the size of the symbol (inset scale). Yellow symbols $=$ trigeminal neuralgia, blue $=$ painful diabetic neuropathy, red $=$ post stroke pain 


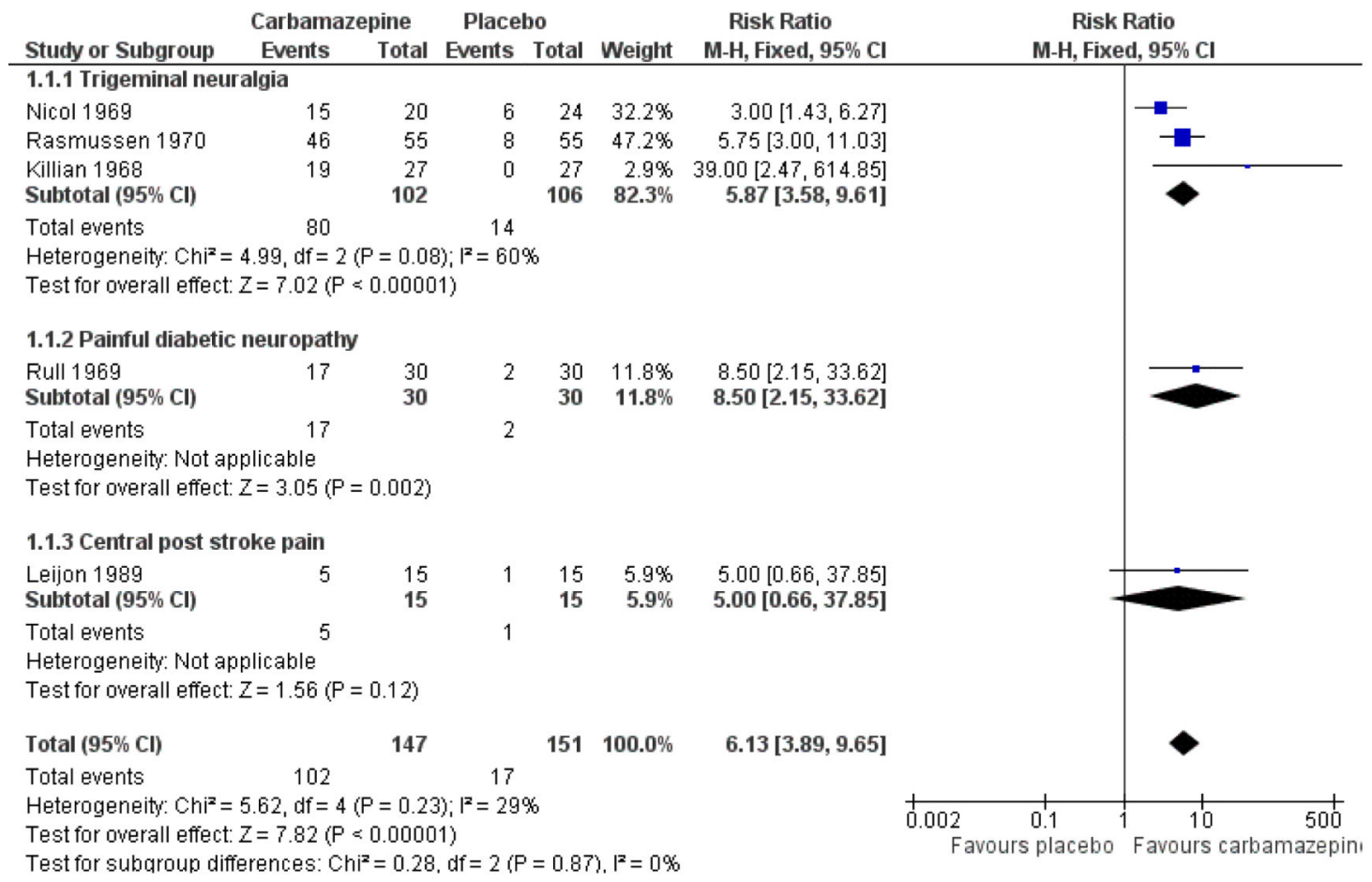

Figure 3.

Forest plot of comparison: 1 Carbamazepine in neuropathic pain, outcome: 1.1 Any pain improvement. 